\title{
Physiology, Metabolism, and Fossilization of Hot-Spring Filamentous Microbial Mats
}

\author{
Yiran Dong, ${ }^{1,2}$ Robert A. Sanford, ${ }^{1,3}$ William P. Inskeep, ${ }^{4,5}$ Vaibhav Srivastava, ${ }^{6}$ Vincent Bulone,, 7 \\ Christopher J. Fields, ${ }^{8}$ Peter M. Yau, ${ }^{8}$ Mayandi Sivaguru, ${ }^{1,9}$ Dag Ahrén, ${ }^{10,11}$ Kyle W. Fouke, ${ }^{1,12}$ \\ Joseph Weber, ${ }^{1}$ Charles R. Werth, ${ }^{1,13}$ Isaac K. Cann, ${ }^{1,14,15}$ Kathleen M. Keating, ${ }^{8}$ \\ Radhika S. Khetani, ${ }^{8}$ Alvaro G. Hernandez, ${ }^{8}$ Chris Wright, ${ }^{8}$ Mark Band, ${ }^{8}$ \\ Brian S. Imai, ${ }^{8}$ Glenn A. Fried, ${ }^{1,9}$ and Bruce W. Fouke ${ }^{1,3,5,8,9,11,15}$
}

\begin{abstract}
The evolutionarily ancient Aquificales bacterium Sulfurihydrogenibium spp. dominates filamentous microbial mat communities in shallow, fast-flowing, and dysoxic hot-spring drainage systems around the world. In the present study, field observations of these fettuccini-like microbial mats at Mammoth Hot Springs in Yellowstone National Park are integrated with geology, geochemistry, hydrology, microscopy, and multi-omic molecular biology analyses. Strategic sampling of living filamentous mats along with the hot-spring $\mathrm{CaCO}_{3}$ (travertine) in which they are actively being entombed and fossilized has permitted the first direct linkage of Sulfurihydrogenibium spp. physiology and metabolism with the formation of distinct travertine streamer microbial biomarkers. Results indicate that, during chemoautotrophy and $\mathrm{CO}_{2}$ carbon fixation, the 87-98\% Sulfurihydrogenibium-dominated mats utilize chaperons to facilitate enzyme stability and function. Highabundance transcripts and proteins for type IV pili and extracellular polymeric substances (EPSs) are consistent with their strong mucus-rich filaments tens of centimeters long that withstand hydrodynamic shear as they become encrusted by more than $5 \mathrm{~mm}$ of travertine per day. Their primary energy source is the oxidation of reduced sulfur (e.g., sulfide, sulfur, or thiosulfate) and the simultaneous uptake of extremely low concentrations of dissolved $\mathrm{O}_{2}$ facilitated by bd-type cytochromes. The formation of elevated travertine ridges permits the Sulfurihydrogenibium-dominated mats to create a shallow platform from which to access low levels of dissolved oxygen at the virtual exclusion of other microorganisms. These ridged travertine streamer microbial biomarkers are well preserved and create a robust fossil record of microbial physiological and metabolic activities in modern and ancient hot-spring ecosystems. Key Words: Filamentous microbial mats-Hotspring-Travertine-Biomarkers-Sulfurihydrogenibium. Astrobiology 19, 1442-1458.
\end{abstract}

${ }^{1}$ Carl R. Woese Institute for Genomic Biology, University of Illinois Urbana-Champaign, Urbana, Illinois, USA.

${ }^{2}$ School of Environmental Studies, China University of Geosciences, Wuhan, China.

${ }^{3}$ Department of Geology, University of Illinois Urbana-Champaign, Urbana, Illinois, USA.

${ }^{4}$ Department of Land Resources and Environmental Sciences, Montana State University, Bozeman, Montana, USA.

${ }^{5}$ Thermal Biology Institute, Montana State University, Bozeman, Montana, USA.

${ }^{6}$ Division of Glycoscience, School of Biotechnology, Royal Institute of Technology (KTH), Stockholm, Sweden.

${ }^{7}$ Division School of Agriculture, Food and Wine, University of Adelaide, Adelaide, Australia.

${ }^{8}$ Roy J. Carver Biotechnology Center, University of Illinois Urbana-Champaign, Urbana, Illinois, USA.

${ }^{9}$ Carl Zeiss Labs @ Location Partner, Carl R. Woese Institute for Genomic Biology University of Illinois at Urbana-Champaign, Urbana, Illinois, USA.

${ }^{10}$ Microbial Ecology Group, Bioinformatics Infrastructure for Life Sciences, Department of Biology, Lund University, Lund, Sweden.

${ }^{11}$ Pufendorf Institute for Advanced Sciences, Lund University, Lund, Sweden.

${ }^{12}$ Department of Geology and Environmental Sciences, Bucknell University, Lewisburg, Pennsylvania, USA.

${ }^{13}$ Department of Civil, Architectural and Environmental Engineering, University of Texas Austin, Texas, USA.

${ }^{14}$ Department of Animal Sciences, University of Illinois Urbana-Champaign, Urbana, Illinois, USA.

${ }^{15}$ Department of Microbiology, University of Illinois Urbana-Champaign, Urbana, Illinois, USA.

(C) Yiran Dong et al., 2019; Published by Mary Ann Liebert, Inc. This Open Access article is distributed under the terms of the Creative Commons Attribution Noncommercial License (http://creativecommons.org/licenses/by-nc/4.0/) which permits any noncommercial use, distribution, and reproduction in any medium, provided the original author(s) and the source are credited. 


\section{Introduction}

$\mathbf{N}$ ASA's HIGHLY INTERDISCIPLINARY Astrobiology Roadmap and its recent update called the Astrobiology Strategy present the scientific foundations required for effective ongoing and future studies of the origin, evolution, composition, and distribution of life throughout the Universe (Des Marais et al., 2008; Hays, 2015). A fundamental component of these efforts is to understand the coevolution and fossilization of microbial life within the context of changing habitable environmental conditions on early Earth and potentially other planets. Microbes initially survive by utilizing and responding to the physical, chemical, and biological parameters of the environments they originated in and colonized. Successful adaptation and evolution can eventually lead these microorganisms to alter and ultimately control these same environmental conditions. Deciphering and predicting these complex feedback processes requires in-depth geology and biology (geobiology) knowledge of the interwoven abiotic and biotic factors that control mineral precipitation, sedimentary rock deposition, and the resulting formation of microbial fossils (biomarkers). To do this, studies of microbial biomarker formation in modern-day terrestrial hot springs on Earth are used to more accurately identify ancient microbial biomarkers and reconstruct the paleoenvironmental conditions they once inhabited (Roling et al., 2015).

Mammoth Hot Springs (MHS) in Yellowstone National Park (YNP; Fig. 1) has long been a strategically important natural laboratory in which to determine how microbial biomarkers form (Fouke et al., 2000, 2003; Fouke 2001, 2011; Kandianis et al., 2008; Veysey et al., 2008). Hotspring calcium carbonate $\left(\mathrm{CaCO}_{3}\right)$ limestone (travertine) is rapidly deposited at MHS to entomb heat-loving (thermophilic) filamentous microorganisms of the order Aquificales. Sulfurihydrogenibium spp., the most abundant of the Aquificales at MHS, exhibits physiological plasticity and catalyzes the growth of $\mathrm{CaCO}_{3}$ (aragonite) crystals to rapidly precipitate thick deposits of sinuous (streamer) travertine. Aquificales is a deeply-rooted evolutionary lineage of the bacteria that thrives in high-temperature, fast-flowing, and dysoxic turbulent water in thermal systems throughout YNP and around the world (Blank et al., 2002; Nakagawa and Fukui, 2003; Aguiar et al., 2004; Ferrera et al., 2007; Purcell et al., 2007; Flores et al., 2008; O'Neill et al., 2008; Inskeep et al., 2013).

Previous studies at MHS have established an extensive quantitative baseline of the physical, chemical, and biological conditions in which Sulfurihydrogenibium-dominated filamentous microbial mats rapidly grow and simultaneously become encrusted to form travertine streamers (Reysenbach et al., 2009; Inskeep et al., 2010, 2013; Fouke, 2011; Hamamura et al., 2013; Takacs-Vesbach et al., 2013). These travertine streamers are composed of (1) fine-scale crystalline preservation of the Sulfurihydrogenibium-dominated filamentous mats that accurately record spring water temperature, $\mathrm{pH}$, and flux; (2) well-preserved lipid biomarker signatures reflecting their sulfur cycling metabolism; and (3) direct catalytic influence on the rate of travertine precipitation (Fouke, 2011). However, several fundamental questions have remained unanswered regarding the specific metabolic pathways utilized by Sulfurihydrogenibium for energy and nutrient assimilation, and how the crystalline record of these processes are preserved and reflected during travertine streamer biomarker formation. The present study documents a direct linkage between Sulfurihydrogenibium physiology and metabolism with resulting travertine microbial biomarker formation. This is accomplished by integrating field observations and analyses of hydrology, aqueous chemistry, and sedimentary petrography (travertine crystalline structure, geochemistry, and geomorphology) with next-generation metagenomic, metatranscriptomic, and metaproteomic approaches. Results establish that fossilized ridged travertine streamer microbial biomarkers sensitively and accurately preserve the physiological and metabolic activities, as well as the environmental conditions, of hotspring filamentous microbial mats.

\section{Geobiological Setting}

Previous long-term studies at MHS have quantitatively characterized the $\mathrm{CO}_{2}$-rich $\mathrm{Ca}-\mathrm{Na}-\mathrm{HCO}_{3}-\mathrm{SO}_{4}$ spring water geochemistry, travertine deposition, and microbial community diversity along the hot-spring outflow drainage systems (Fouke, 2011). Temperature and $\mathrm{pH}$ measurements in the context of a travertine depositional facies model (described below) at Narrow Gauge Spring within the MHS thermal complex (Fig. 1) were used here to correlate with these previously published analyses. This permitted a comprehensive environmental contextualization of the Sulfurihydrogenibiumdominated filamentous microbial mats analyzed in the present study (Fouke et al., 2003; Inskeep et al., 2010, 2013; Fouke, 2011; Hamamura et al., 2013; Takacs-Vesbach et al., 2013) (Supplementary Table S1; Supplementary Information is available online at www.liebertonline.com/ast).

The MHS drainage systems are composed of a sequence of five distinct types of upstream-to-downstream travertine rock deposits (facies) composed of unique crystal sizes and shapes, mineralogies, chemistries, and geomorphologies (Fouke et al., 2000; Fouke, 2011). Each of these facies rock deposits reflects a specific combination of physical, chemical, and biological processes that were active in the hotspring environment that formed each unique facies. The composition and succession of each travertine facies, including the Apron and Channel Facies (ACF) that is the focus of the present study, is consistently reestablished after the hot-spring vents shift their position, close, or reemerge elsewhere in the MHS system (Fouke et al., 2000; Fouke, 2011). As a result, the crystalline fabric and geomorphology of modern and ancient ACF travertine deposits can be used to accurately and reproducibly reconstruct temperature, $\mathrm{pH}$, hydrology and other environmental factors (Veysey et al., 2008; Fouke, 2011). The MHS travertine facies model has also been proven to be directly applicable to other modern and ancient travertine-depositing hot-spring ecosystems around the world (Fouke 2001; Veysey et al., 2008).

The present study focuses on the high-temperature (65$72^{\circ} \mathrm{C}$ ) and low-pH (6.2-6.8) environment where sinuous ACF travertine deposits are formed when Sulfurihydrogenibiumdominated microbial mat streamers are encrusted by densely packed radial bundles of needle-like (acicular) $\mathrm{CaCO}_{3}$ aragonite crystals (Fig. 1) (Fouke et al., 2000; Fouke, 2011). Here, travertine mimics the morphology of the ACF filamentous microbial mats, which forms a well-preserved travertine 

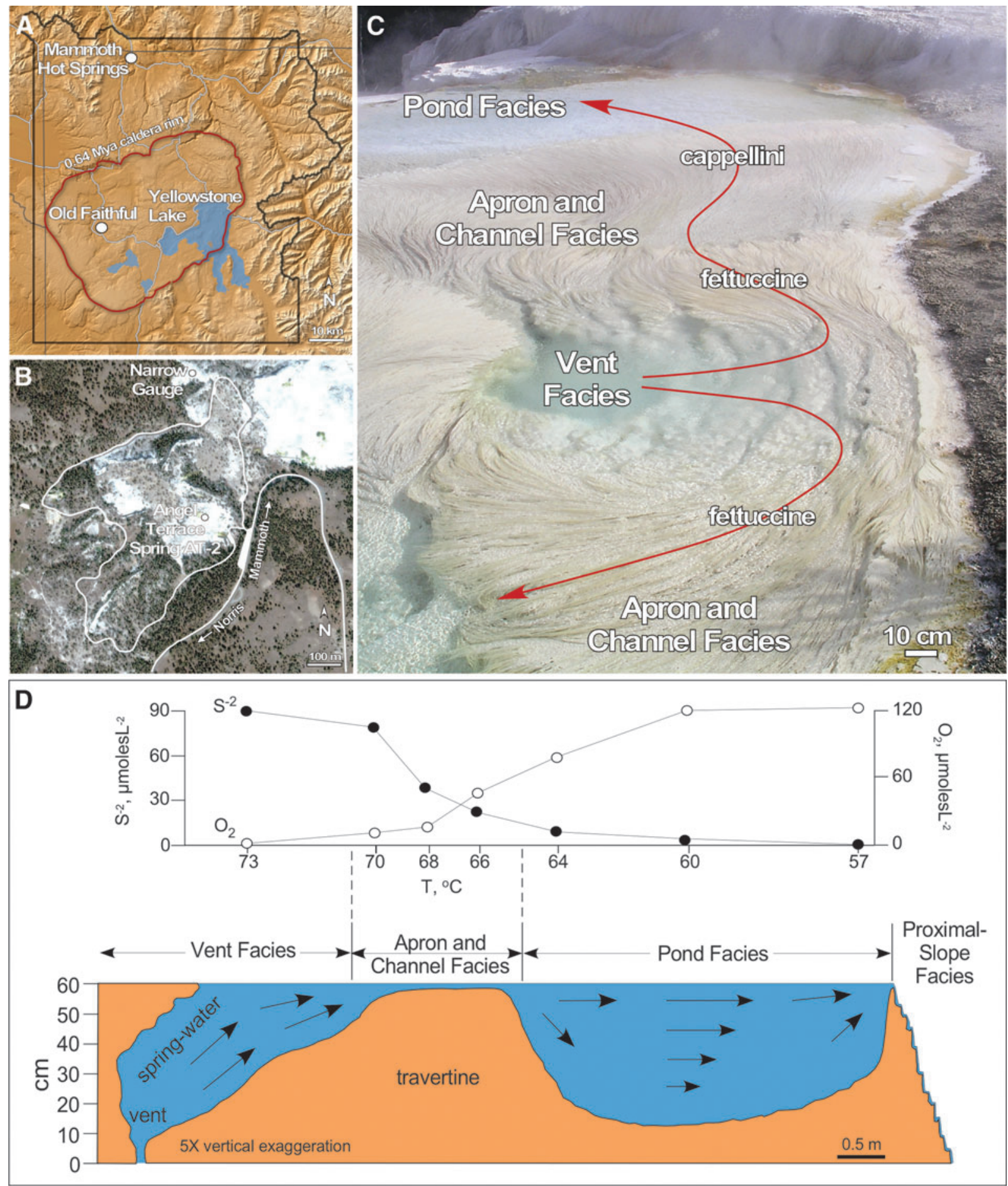

FIG. 1. (A) Map of Yellowstone National Park. (B) Satellite image of MHS. (C) Field photograph overview of a spring outflow at MHS. (D) Cross section of the Vent, Apron and Channel, and Pond Facies with quantified physical and chemical conditions. B, C, and D are modified from Fouke (2011) and Fouke and Murphy (2016).

microbial biomarker (Veysey et al., 2008). The upstream 69$72^{\circ} \mathrm{C}$ portion of the ACF depositional environment forms pasta-like travertine deposits called the "fettuccini" streamer fabric (Fig. 1). In these locations, bundles of intertwined microbial filaments can reach $2 \mathrm{~mm}$ in diameter and $10 \mathrm{~cm}$ in length (Fouke, 2011). Aragonite travertine entombment is minimal at the downstream growing tips of each horizontal filament and rapidly increases upstream along each filament
(Figs. 2 and 3). A suite of reduced sulfur compounds including sulfide ( $\mathrm{HS}^{-}$aqueous), thiosulfate $\left(\mathrm{S}_{2} \mathrm{O}_{3}{ }^{2-}\right.$ aqueous), sulfur $\left(\mathrm{S}^{0}\right.$ solid), reduced arsenic species and dissolved inorganic carbon (DIC) are important geochemical components in these upstream portions of the MHS drainage systems (Fouke, 2011).

Molecular microbial ecology studies of the ACF fettuccini streamer travertine depositional environments consistently indicate they are composed of stable and relatively low-diversity 

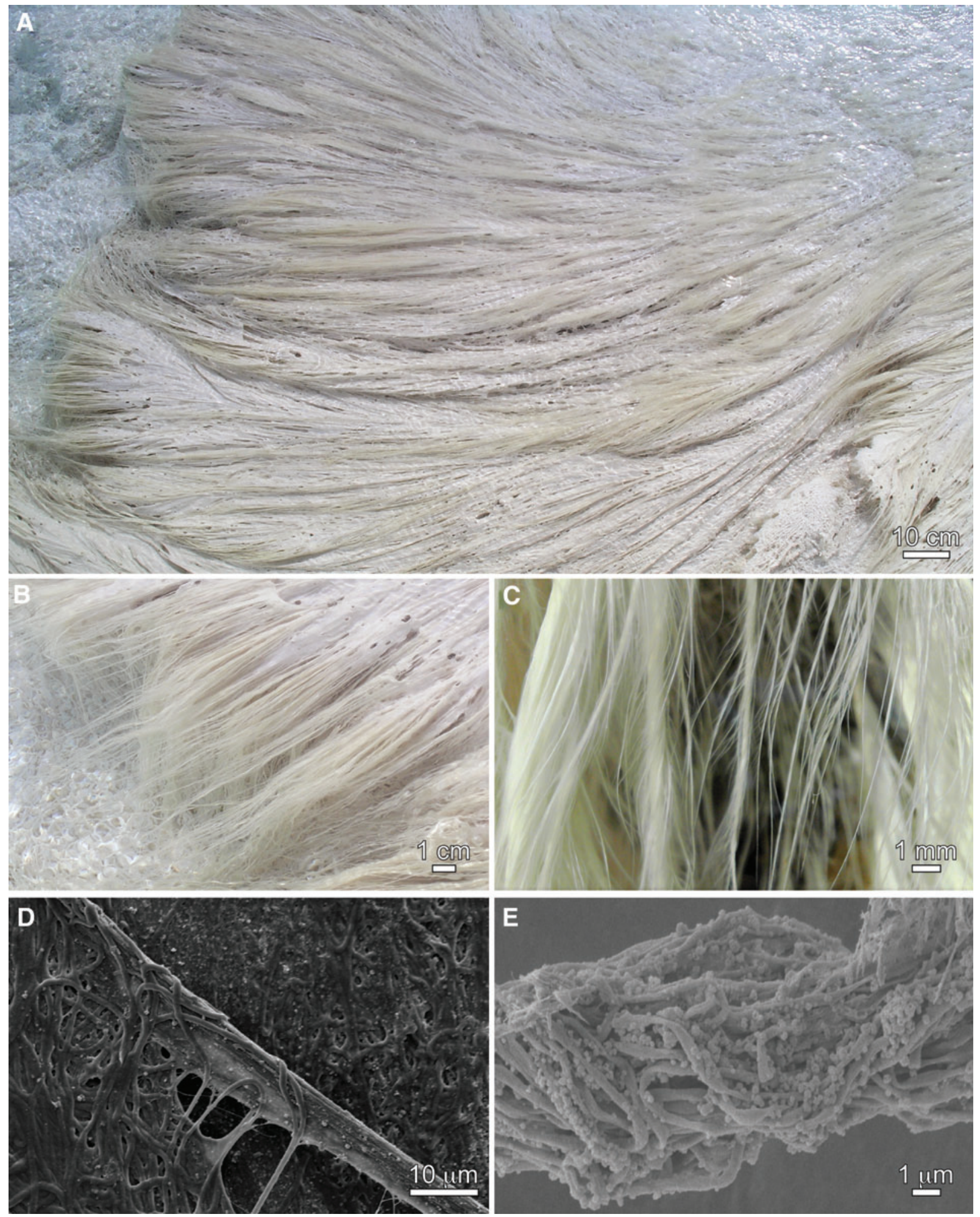

FIG. 2. Sulfurihydrogenibium-dominated filamentous microbial mats inhabiting the ACF. (A) Field photograph of the fettuccini streamer travertine. (B and C) Naked microbial filaments not yet encrusted by travertine. (D and $\mathbf{E}$ ) Scanning electron photomicrographs of the naked microbial filaments. A, B, and E are modified from Fouke (2011) and Fouke and Murphy (2016).

microbial communities dominated by Sulfurihydrogenibium spp. (Fouke et al., 2003). Recent metagenomic and metatranscriptomic analyses of Sulfurihydrogenibium isolates from YNP have substantiated this community structure and permitted reconstruction of their basic metabolic strategies (Reysenbach et al., 2009; Inskeep et al., 2010, 2013; Hamamura et al., 2013; Takacs-Vesbach et al., 2013). This work has shown that Sulfurihydrogenibium spp. are chemolithoautotrophic sulfur oxidizers that fix $\mathrm{CO}_{2}$ using the reductive reversed tricarboxylic acid (rTCA) cycle. Sulfurihydrogenibium azorense and 

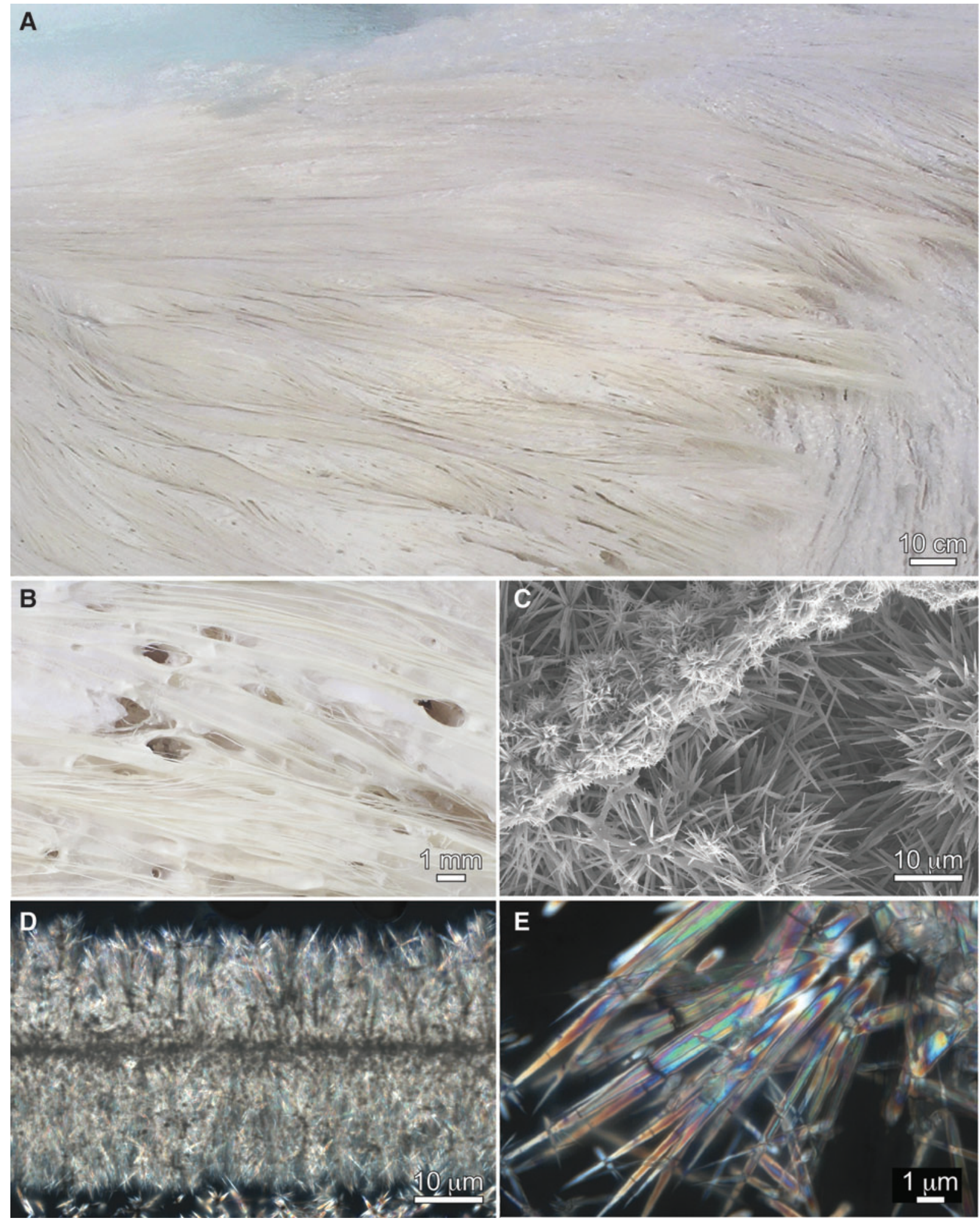

FIG. 3. Sulfurihydrogenibium-dominated filamentous microbial mats inhabiting the ACF. (A) Field photograph of the fettuccini streamer travertine. (B) Elliptical holes torn in the sheets of EPSs draped between filaments. (C) Scanning electron photomicrographs of small aragonite needles encrusting microbial filaments and large aragonite needles encrusting interfilament EPSs. (D and E) Polarized bright-field photomicrograph of aragonite needles encrusting a microbial filament. C, D, and E are modified from Fouke (2011) and Fouke and Murphy (2016). 
S. kristjanssonii (Aguiar et al., 2004; Flores et al., 2008) contain Group $1 \mathrm{Ni}$-Fe hydrogenases and can oxidize hydrogen. However, these genes were absent in the metagenomes of ACF streamer communities at MHS (Inskeep et al., 2010; TakacsVesbach et al., 2013). This observation, coupled with the absence of Group I Ni-Fe hydrogenases in the Sulfurihydrogenibium yellowstonense genome (Reysenbach et al., 2009), and the inability of this organism to grow on hydrogen, suggests that these microbial communities utilize other electron donors to drive the fixation of inorganic carbon.

\section{Materials and Methods}

Detailed description of all protocols and techniques used for field collection, biomolecule extractions, and meta-omic analyses are presented in the Supplementary Information and briefly summarized here. Detailed descriptions of the experimental design and metadata curation strategies adopted for all aspects of the field and laboratory analyses in the present study are presented in the works of Palmer et al. (2017) and Thomer et al. (2018).

\subsection{Yellowstone field sample collection}

Filamentous microbial mat samples were collected from ACF fettuccini streamer travertine depositional environments (Fig. 2) at Narrow Gauge Spring $\left(44^{\circ} 54^{\prime} 17.46^{\prime \prime} \mathrm{N}\right.$, $\left.110^{\circ} 24^{\prime} 14.5^{\prime \prime} \mathrm{W}\right)$ in the MHS thermal complex. Quantitative physical, chemical, and biological measurements of the environmental conditions in which the ACF travertine within the MHS facies model is deposited have previously been published (Fouke et al., 2003; Inskeep et al., 2010, 2013; Fouke, 2011; Hamamura et al., 2013; Takacs-Vesbach et al., 2013). In addition to the streamer travertine morphology and crystalline structure, the precise correlation with previously published ACF environmental parameters was confirmed with measurements of temperature and $\mathrm{pH}$ using an Orion Model 290A probe (Veysey et al., 2008). Filamentous microbial mat samples were collected from the most distal portions of the ACF fettuccine streamer travertine depositional environment (Fig. 2A, 2B) and shipped overnight in a $-80^{\circ} \mathrm{C}$ Taylor-Wharton CX100 dry shipper liquid nitrogen dewar to the Carl R. Woese Institute for Genomic Biology at the University of Illinois at Urbana-Champaign.

\subsection{Nucleic acid extraction and analyses}

Genomic DNA and RNA were extracted in the Carl R. Woese Institute for Genomic Biology from the centrifuged pellets by using a procedure modified from Dong et al. (2014) and Inskeep et al. (2010). One gram of microbial mat pellet was derived from each of two separate replicate samples collected from the spring, pooled, and mixed for extraction. Frozen samples were thawed on ice and centrifuged at $9000 \mathrm{rpm}$ on a SORVALL Legend RT centrifuge (Fisher Thermo Scientific Inc., MA) at $4^{\circ} \mathrm{C}$ for $20 \mathrm{~min}$, after which the supernatant was carefully decanted. The remaining pellets were incubated for $0.5 \mathrm{~h}$ with $2 \mathrm{~mL}$ of lysis buffer $(0.15 \mathrm{M}$ $\mathrm{NaCl}, 0.1 \mathrm{M} \mathrm{Na}_{2}$ EDTA, $\mathrm{pH}=8.0$ ) containing $15 \mathrm{mg} / \mathrm{mL}$ lysozyme (Sigma-Aldrich, MO) at $37^{\circ} \mathrm{C}$. This step was repeated once, and the supernatant for the two rounds of lysis was decanted and pooled (Inskeep et al., 2010). The supernatant was then incubated with equal amount of SDS-Tris solution $(0.1 \mathrm{M} \mathrm{NaCl}, 0.5 \mathrm{M}$ Tris-Cl, $\mathrm{pH}=8.0,10 \%$ sodium dodecyl sulfate). Freeze-thaw cycling between a $55^{\circ} \mathrm{C}$ water bath and liquid nitrogen was performed three more times to ensure further cell wall lysis, followed with incubation for $0.5 \mathrm{~h}$ with proteinase $\mathrm{K}(100 \mu \mathrm{g} / \mathrm{mL})$. Phenol:chloroform extractions and precipitation were performed following the methods presented in the work of Dong et al. (2014). Samples were placed in $100 \mu \mathrm{L}$ TE buffer ( $\mathrm{pH} 7.4$ ), with the quality and quantity of recovered DNA and RNA confirmed by gel electrophoresis. The extracted DNA and RNA were then loaded onto a $1.0 \%$ agarose gel and stained with ethidium bromide. The size and intensity of the genomic DNA and RNA bands were compared visually with a quantitative DNA ladder (Hyperladder I, Bioline USA, Boston, MA).

\subsection{Protein and peptide extraction and analyses}

Metaproteomic analyses of the ACF fettuccini streamer microbial community were conducted by using multiple extraction and analysis methods at the Division of Glycoscience, Royal Institute of Technology (KTH), Sweden, and the Roy J. Carver Biotechnology Center, University of Illinois Urbana-Champaign. The protein extractions were performed on the streamer microbial mat samples that had been thawed at $4^{\circ} \mathrm{C}$. Four different extraction protocols and two protein analysis methods were used in the independent Illinois and Stockholm laboratories to obtain and compare protein and peptide recovery, thus permitting the potential bias of any individual methodology (described in the Supplementary Information).

The peptides simultaneously matching two or more proteins (non-unique) were excluded from the following analyses. A protein was considered as "identified" when it had at least one unique peptide hit, and those with no unique peptides (e.g., only identified by shared peptides) were excluded. In addition, only the proteins, which contained at least two unique peptides from one method or were identified in no less than two different extraction/analysis methods, were used for the following analyses. The protein identifications were exported with a protein probability $p$ value (Mascot) of greater than 0.05 (peptide 0.95 ). The false discovery rate was $9-21 \%$, which is high due to the limited comparative data base for natural hot-springs and the short length of the transcriptomic reads. However, all protein identification inferences were consistently corroborated by both the protein probability $p$ value and metagenomic analyses. The relative abundance of each identified protein was calculated by using normalized spectral abundance factor, which considered both abundance and size of the protein (Zybailov et al., 2006). The taxonomy and annotation of the identified proteins were retrieved from the open reading frames (ORFs) predicted from the metagenome of the same ACF fettuccini microbial community (as described above). The proteins detected from the libraries by using four different extraction methods were pooled for identification of unique proteins. This was then integrated with the results from metagenomic and metatranscriptomic analyses for metabolic reconstruction.

\subsection{Bioinformatic and statistical analyses}

Bioinformatic analyses were completed at the Roy J. Carver Biotechnology Center at the University of Illinois Urbana-Champaign. Metagenome assembly and phylogenetic 
binning were performed as described in the Supplementary Methods. Comparative genomic analyses were performed with OrthoVenn (Wang et al., 2015). ORFs assigned to the Sulfurihydrogenibium were extracted for metabolic reconstruction and predicted by using IMG/MER's native collection of pathways (Markowitz et al., 2012). These were manually curated based on available literature about Aquificales and their associated microbial communities in thermal and hyperthermal environments. Clusters of orthologous groups of proteins (COGs) that were significantly enriched or over-presented in cDNA dataset relative to DNA dataset at 0.95 confidence level were identified with XIPE, a nonparametric, difference-of-medians analysis method (RodriguezBrito et al., 2006). Only the metabolic pathways containing ORFs with enriched transcription as well as expressed proteins were considered.

\subsection{Data accession}

The reads of the V3-V5 hypervariable region of the 16S rRNA genes are available in the Short Reads Archive (SRA; SRR4444881). The raw sequencing of reads and assembled contigs for the metagenomic and metatranscriptomic libraries of the ACF fettuccini streamer microbial community are available in the SRA (SRR4436414-SRR4436415) and
Whole Genome Shotgun (WGS) under accession number (SRX2255526, SRX2255527). The genomes of the dominant Sulfurihydrogenibium spp. are available in the IMG/ER under the IMG Submission ID 79768. Mass spectrometry proteomics data has been deposited in the ProteomeXchange Consortium via the PRIDE partner repository with the dataset identifier PXD004323 and PXD006504-PXD006506.

\section{Results}

Field observations, optical microscopy, and scanning electron microscopy for the MHS ACF depositional environment have previously been published (Fouke et al., 2000; Kandianis et al., 2008; Veysey et al., 2008; Fouke, 2011). Our newly collected metagenomic, metatranscriptomic, and metaproteomic analyses suggest that filamentous mats growing within the ACF depositional environment at Narrow Gauge Spring are dominated by Sulfurihydrogenibium spp. (Supplementary Information). Fully $87 \%$ of the metagenomic reads and $88 \%$ of the metatranscriptomic libraries align with the Sulfurihydrogenibium pangenome B001 (Figs. 4-6). This pangenome is effectively a metagenome assembled genome. Metaproteomic results indicate that 533 out of 665 unique proteins were associated with the pangenome (Fig. 6). The metaproteomic library, constructed by using combined sodium dodecyl sulfate

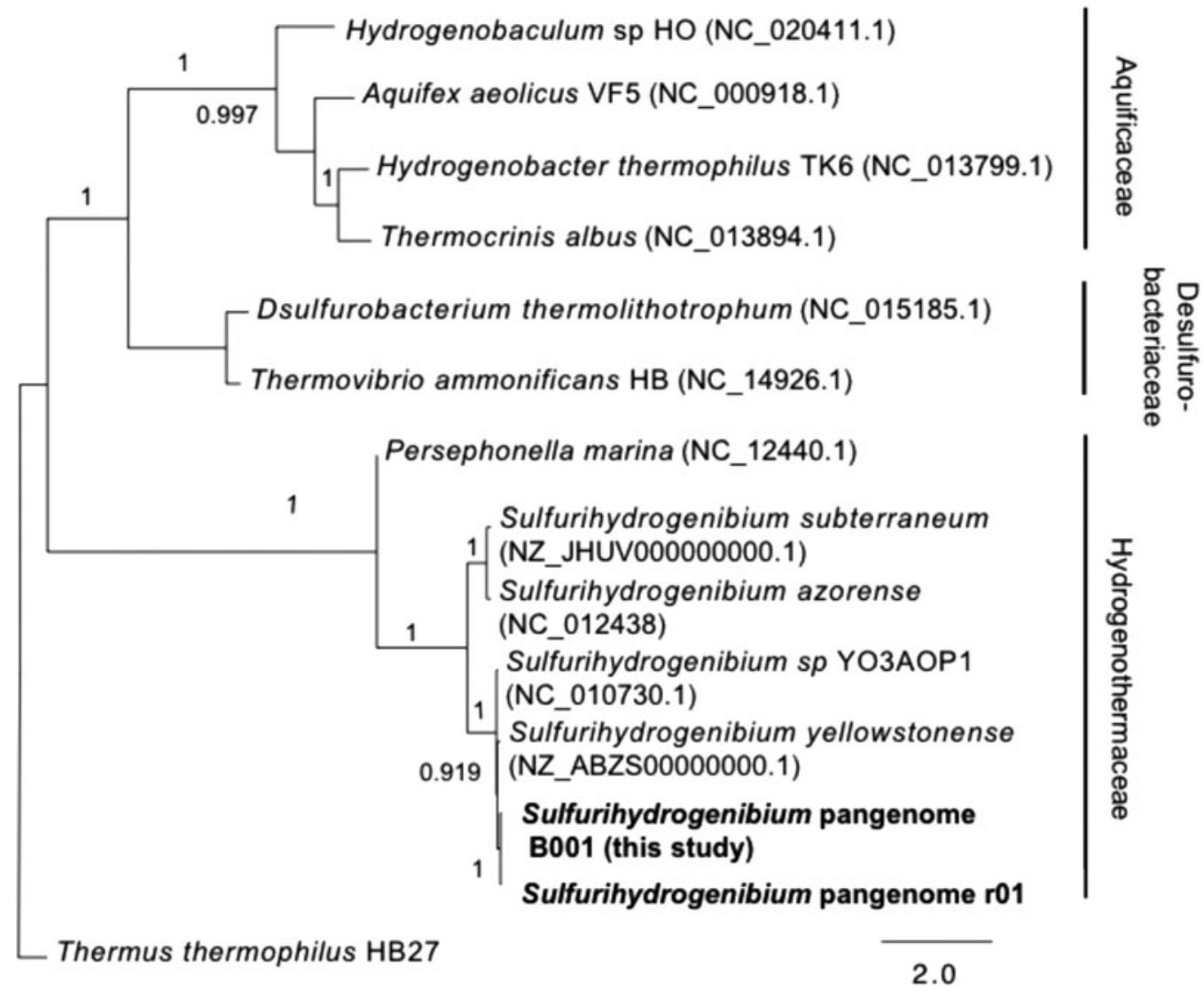

FIG. 4. A phylogenomic tree reconstruction based on available pangenomes and genomes (phylogenomic trees) related to the Sulfurihydrogenibium spp.-dominated filamentous microbial mats analyzed in the present study. Sulfurihydrogenibium pangenome B001 and the closely related Aquificales. Sulfurihydrogenibium pangenome r01 are the terms used for the curated Sulfurihydrogenibium pangenome reconstructed from the metagenomes of previously reported microbial communities associated with the ACF depositional environment at MHS (Inskeep et al., 2010, 2013; Takacs-Vesbach et al., 2013). The scale bar indicates genetic substitutions of $2 \%$ per unit of the sequence length. Values next to the nodes are pping values. Identification numbers in parentheses are the genome accession numbers shown in the NCBI bacterial genome database. 


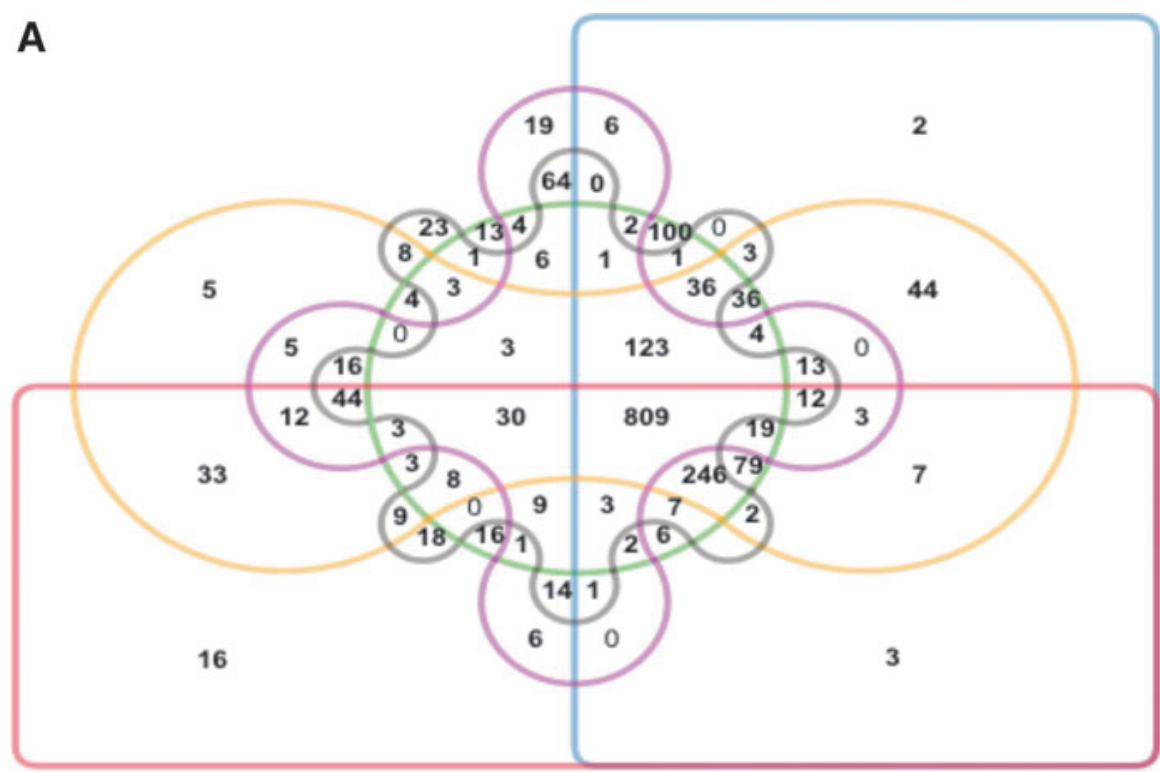

809 shared by 6 (pan)genomes 433 shared by 5 (pan)genomes 215 shared by 4 (pan)genomes 119 shared by 3 (pan)genomes 212 shared by 2 (pan)genomes 78 unique ones in individual (pan)genomes
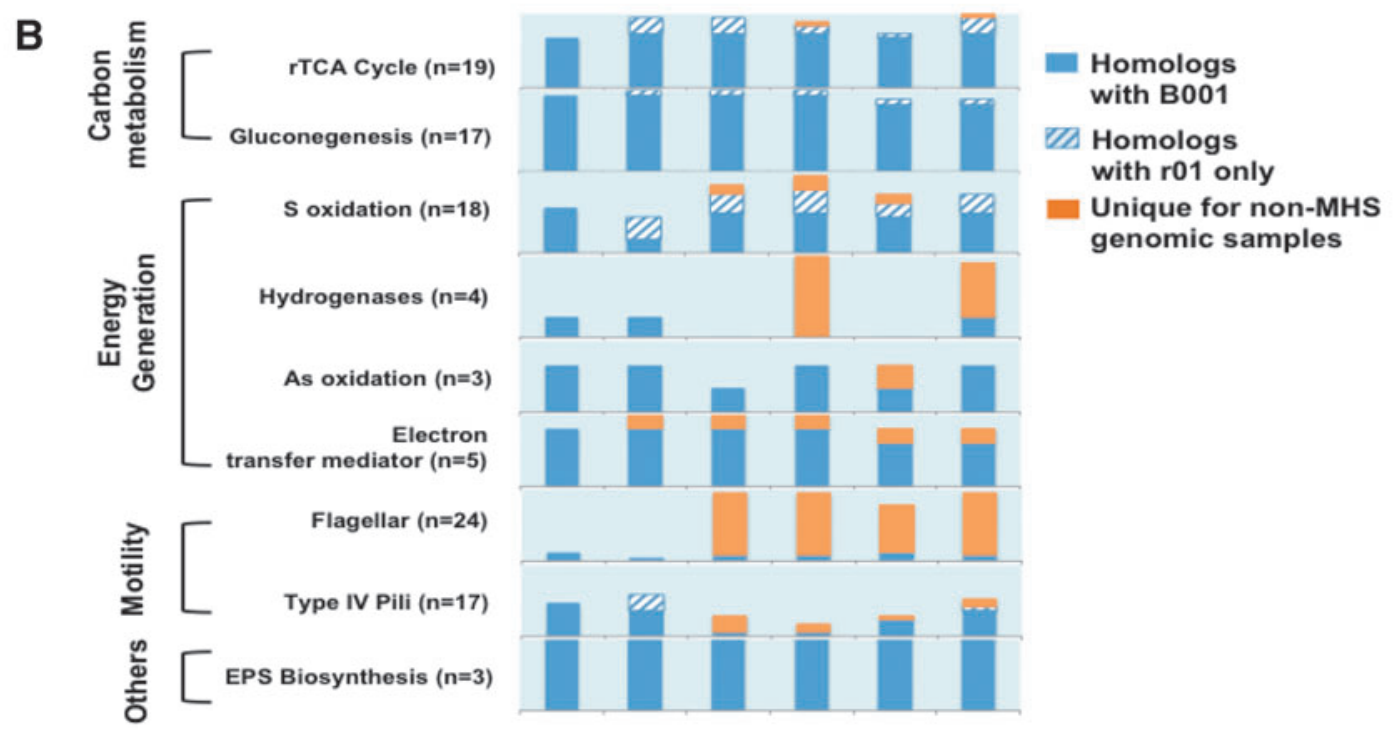
genomic samples

FIG. 5. Comparative genomic analyses (A) and gene distribution for individual metabolic function (B) for the Sulfurihydrogenibium pangenomes and the known Sulfurihydrogenibium genomes. In A, the annotation was conducted with IMG, and the metabolic pathways were determined with KEGG (Markowitz et al., 2012). These comparative genomic analyses were conducted using OrthoVenn (Wang et al., 2015) with an e-value of $1 \mathrm{e}^{-10}$ and inflation value 1.5 . The values indicated the number of protein clusters shared between the Sulfurihydrogenibium pangenomes and genomes; those highlighted in red meant the number of protein clusters unique for the MHS-YNP ACF Sulfurihydrogenibium pangenomes but absent in the known Sulfurihydrogenibium genomes. In B, the fractions in percentile were calculated by dividing the number of proteincoding genes affiliated to a specific metabolic function for individual genome/pangenome by the nonredundant value for those of all the Sulfurihydrogenibium genome and pangenomes under investigation. The values in parentheses indicated the total number of genes counted for each metabolic function with the detailed information listed in Table S4. 
A

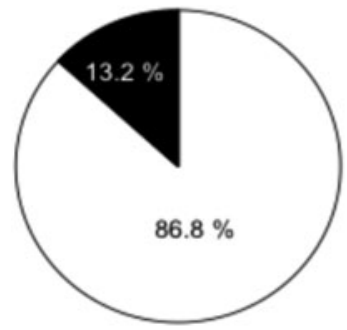

B

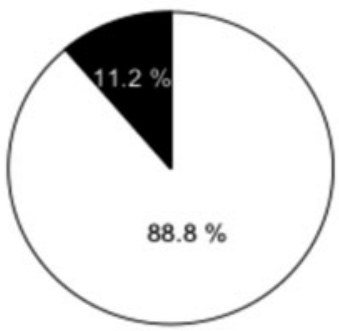

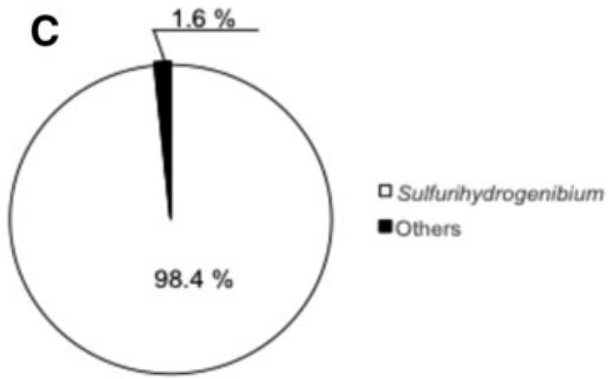

FIG. 6. Dominance of Sulfurihydrogenibium spp. in the filamentous microbial communities based on taxonomic assignments of the non-rRNA genes, mRNA transcripts, and proteins in the metagenomic (A), metatranscriptomic (B), and metaproteomic (C) libraries showed. The values listed indicate relative abundance in percent. Proteomic analyses indicate proteins recovered using integrated SDS lysis and in-gel digestion as the reference library for three pooled protein extraction methods.

(SDS) lysis and in-gel digestion extraction methods (Supplementary Information), has $98.4 \%$ of its peptides assigned to the Sulfurihydrogenibium pangenome B001 (Figs. 6 and S1, Table S4). The Sulfurihydrogenibium pangenome B001 functional profile is built upon COGs (Tatusov et al., 2000) of functional protein categories determined for genes, transcripts, and proteins from the metagenomic, metatranscriptomic, and metaproteomic libraries (Table 1; Fig. 5). In comparison, the relative abundance of the sequences in these libraries across 19 COG categories was more evenly distributed in the metagenome $(0.53-10.46 \%)$ than in the metatranscriptomic library $(0.35-27.81 \%)$ and proteomic library $(0.29-29.66 \%)$ as expected (Figs. 6 and S4). The COG categories "C-energy production and conversion," "O-post-translational modification," and "N-Cell motility" were significantly over-represented in the metatranscriptomic and metaproteomic libraries (Fig. 7).

Further evaluation of the protein classes affiliated with all COG categories with bootstrapping analyses (RodriguezBrito et al., 2006) indicated that a total of 17 protein classes have elevated expression levels for the dominant Sulfurihydrogenibium pangenome (Fig. 7). This is shown by their significant enrichment in the metatranscriptomic library relative to the metagenomic library (95\% confidence level; Table 1). Analyses of these over-represented protein classes showed that the majority of them corresponded to the most abundant $(n=40)$ transcripts in terms of fragments per kilobase of exon per million fragments mapped (FPKM). The cognate proteins were also identified for most of these over-represented protein-coding genes (Fig. 7). Evaluation of the over-represented genes and cognate proteins showed that they were closely associated with nutrient metabolism (e.g., rTCA cycle), energy generation (e.g., sulfur oxidation) and tolerance of environmental stresses (e.g., chaperonins, putative cold shock proteins, type IV pili, and EPS biosynthesis) by the Sulfurihydrogenibium spp. (Fig. 8; Tables S6-S10). Importantly, comparative genomic analyses reveal that the MHS Sulfurihydrogenibium has several genetic traits that are distinct from those communities inhabiting other geographically isolated geothermal environments (Reysenbach et al., 2009). In addition, differences are observed in the functional genes comprising the two MHS pangenomes (Fig. 4, Table S6).

Table 1. COGs That Are Significantly Enriched in the cDNA Dataset Relative to the DNA Dataset at 0.95 Confidence LeVel

\section{COG Cluster}

\begin{tabular}{cc}
$\begin{array}{c}\text { Representation } \\
\text { in } \text { cDNA (\%) }\end{array}$ & $\begin{array}{c}\text { Representation } \\
\text { in DNA (\%) }\end{array}$ \\
\hline $9.58 \mathrm{e}-1$ & $1.90 \mathrm{e}-3$ \\
3.29 & $1.67 \mathrm{e}-3$ \\
$3.50 \mathrm{e}-1$ & $6.34 \mathrm{e}-4$ \\
1.01 & $2.24 \mathrm{e}-4$ \\
$9.38 \mathrm{e}-2$ & $5.42 \mathrm{e}-3$ \\
1.03 & $9.20 \mathrm{e}-4$ \\
$5.41 \mathrm{e}-1$ & $7.16 \mathrm{e}-4$ \\
$9.83 \mathrm{e}-1$ & $1.64 \mathrm{e}-3$ \\
$5.79 \mathrm{e}-1$ & $7.49 \mathrm{e}-4$ \\
& \\
1.43 & $1.24 \mathrm{e}-3$ \\
2.83 & $2.54 \mathrm{e}-3$ \\
$6.09 \mathrm{e}-1$ & $1.30 \mathrm{e}-3$ \\
$8.98 \mathrm{e}-2$ & $5.78 \mathrm{e}-3$ \\
1.64 & $2.27 \mathrm{e}-3$ \\
$8.93 \mathrm{e}-1$ & $3.74 \mathrm{e}-4$ \\
1.12 & $9.69 \mathrm{e}-4$ \\
\hline
\end{tabular}

Succinyl-CoA synthetase, beta subunit (COG0045)

GTPases - translation elongation factors (COG0050)

Succinyl-CoA synthetase, alpha subunit (COG0074)

Co-chaperonin GroES (HSP10) (COG0234)

Glycosyltransferase (COG0438)

Chaperonin GroEL (HSP60 family) (COG0495)

Succinate dehydrogenase/fumarate reductase, Fe-S protein subunit (COG0479)

Translation elongation factors (COG0480)

Pyruvate:ferredoxin oxidoreductase or related

2-oxoacid:ferredoxin oxidoreductase, alpha subunit (COG0674)

NADH dehydrogenase, FAD-containing subunit (COG1252)

Cytochrome bd-type quinol oxidase, subunit 1 (COG1271)

Cytochrome c, mono- and diheme variants (COG2010)

Cation transport ATPase (COG2217)

Monomeric isocitrate dehydrogenase (COG2838)

Cytochrome c551/c552 (COG4654)

Tfp assembly protein FimT (COG4970)

$9.69 \mathrm{e}-4$

${ }^{\text {a }}$ Significantly enriched in cDNA sample at the 0.95 confidence level based on the bootstrapping statistic method (Rodriguez-Brito et al., 2006). 


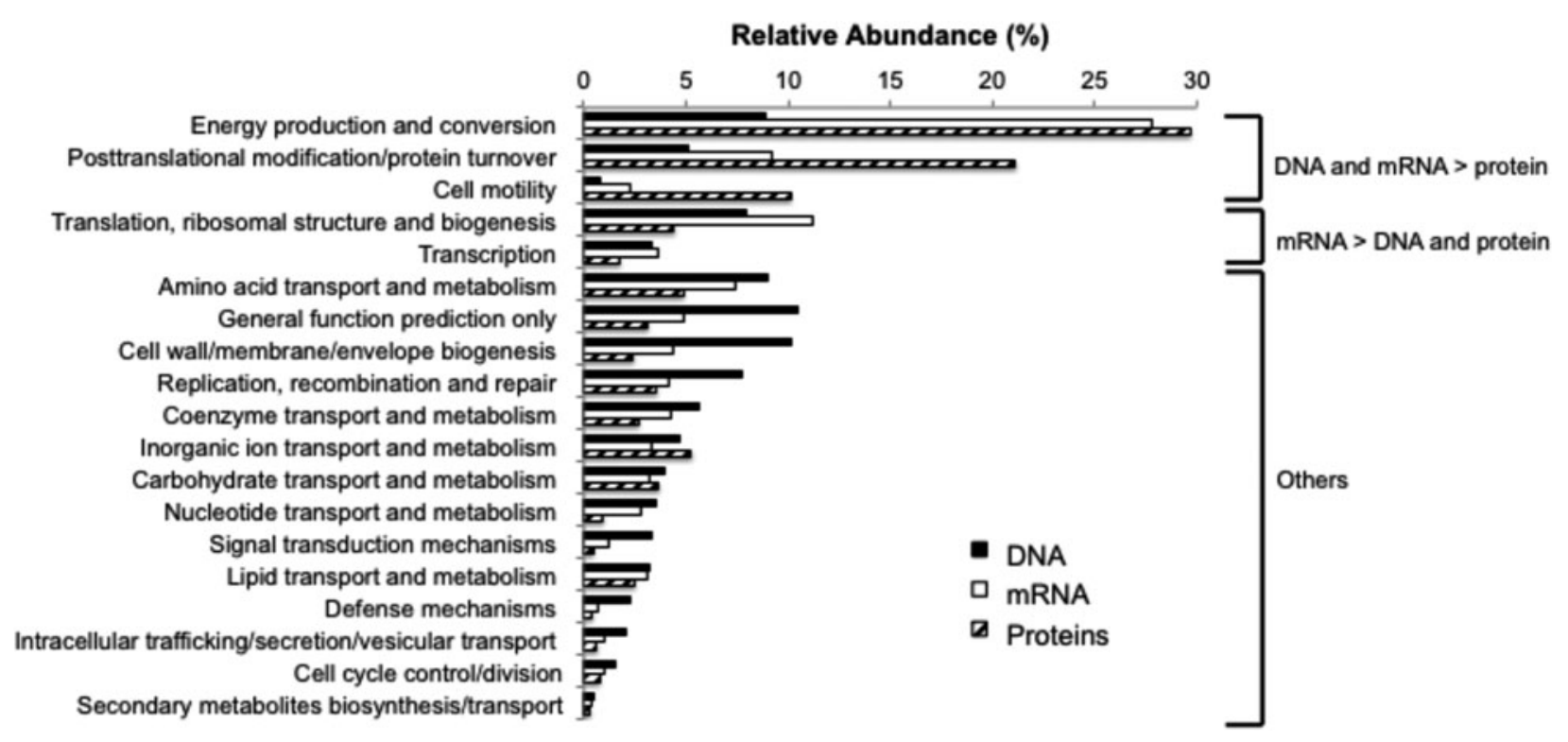

FIG. 7. Gene expression profiles at DNA, mRNA transcript, and protein levels based on the COG protein family database for the dominant Sulfurihydrogenibium spp. The cutoff value for the COG categories under consideration was $0.1 \%$. The dataset from protein analyses was from the proteomic library developed on the combined SDS lysis and in-gel digestion method.

\section{Discussion}

\subsection{Sulfurihydrogenibium pangenome structure and diversity}

The Sulfurihydrogenibium pangenome B001 detected in the present study represents multiple closely related microorganisms based on repeated single-copy genes. Only one $16 \mathrm{~S}$ rRNA gene sequence at nearly full length is observed in the present study, compared with the detection of four 16S rRNA gene sequences previously observed in Sulfurihydrogenibium pangenome r01 (Inskeep et al., 2010, 2013; Takacs-Vesbach et al., 2013). While this may in part be due to the clustering of sequences at the $97 \%$ sequence identity level (Miller et al., 2011), it may also imply that the low-diversity ACF filamentous mats have an unexpectedly diverse genome structure. This pangenome comparison further suggests that proteincoding genes for carbon metabolism and extracellular polymeric substance (EPS) biosynthesis are relatively conserved. In contrast, while all Sulfurihydrogenibium pangenomes contain functional genes for sulfur oxidation, differences have been reported in their capacity to metabolize different sulfurcontaining substrates (Takai et al., 2003; Aguiar et al., 2004; Nakagawa et al., 2005; Flores et al., 2008; O'Neill et al., 2008). In addition, the two ACF Sulfurihydrogenibium pangenomes lack nearly all the functional genes associated with biosynthesis and assembly of flagella (Fig. 5 and Table 1), which are expressed in all the other known Sulfurihydrogenibium isolates (Takai et al., 2003; Aguiar et al., 2004; Nakagawa et al., 2005; Flores et al., 2008; O'Neill et al., 2008; Reysenbach et al., 2009). Another distinct difference is that genes associated with type IV pili are present in the MHS ACF pangenome yet absent in Sulfurihydrogenibium genomes from other geochemically distinct hot-springs in other geographic locations (Fig. 4 and Table S6).

While the ACF filamentous microbial mat communities are 90\% distinct from those detected in the other four upstream-todownstream travertine facies depositional environments at
MHS (Fouke et al., 2003), pangenome comparisons imply that there is also strain-level genetic diversity between similar Sulfurihydrogenibium spp. The suite of genes encoding sulfuroxidizing proteins (i.e., sox $A B X Y Z$ ) that catalyze the oxidation of thiosulfate to sulfate is only expressed in analyses from the present study. These genes were not previously detected in Sulfurihydrogenibium pangenome r01 (Table S2; Inskeep et al., 2013; Takacs-Vesbach et al., 2013). Furthermore, the sulfide:quinone oxidoreductase and sulfide dehydrogenase predicted in Sulfurihydrogenibium pangenome r01appear to be substituted with a putative sulfide-quinone reductase with relatively low homology in the newest pangenome (Tables S2 and S6). These Sulfurihydrogenibium pangenomes are not complete, and gaps between scaffolds exist. However, their dominance in the microbial communities and the more than 98\% completeness of the reconstructed pangenomes imply that the absence of a whole suite of functional genes (e.g., soxABXYZ) in the Sulfurihydrogenibium pangenome $\mathrm{r} 01$ is likely not from the limited coverage in sequencing or assembly. Alternatively, this may be due to the physical and geochemical gradient within the ACF itself and thus reflect spatial population diversity on a relatively small scale.

With respect to sulfur compounds, the concentration of sulfide decreases from about 90 to $20 \mu \mathrm{M}$ from upstream to downstream in the ACF, while the thiosulfate ranges from 45 to $90 \mu \mathrm{M}$ with the peak concentration in the intermediate zone (Fig. 1; Fouke et al., 2003; Fouke, 2011). Sampling for the present study was completed from flowing springwater with lower $\mathrm{pH}$ but higher sulfide concentrations compared to sampling conducted in previous work (Inskeep et al., 2013; Takacs-Vesbach et al., 2013). Previous analyses of four upstream-to-downstream sites within the ACF detected several different Sulfurihydrogenibium 16S rRNA phylotypes (Table S5). The dominant Sulfurihydrogenibium phylotype identified in the current study is most similar to those detected in the upper reaches of the ACF (fettuccini microbial community; Table S5), which is consistent with the location in which samples 


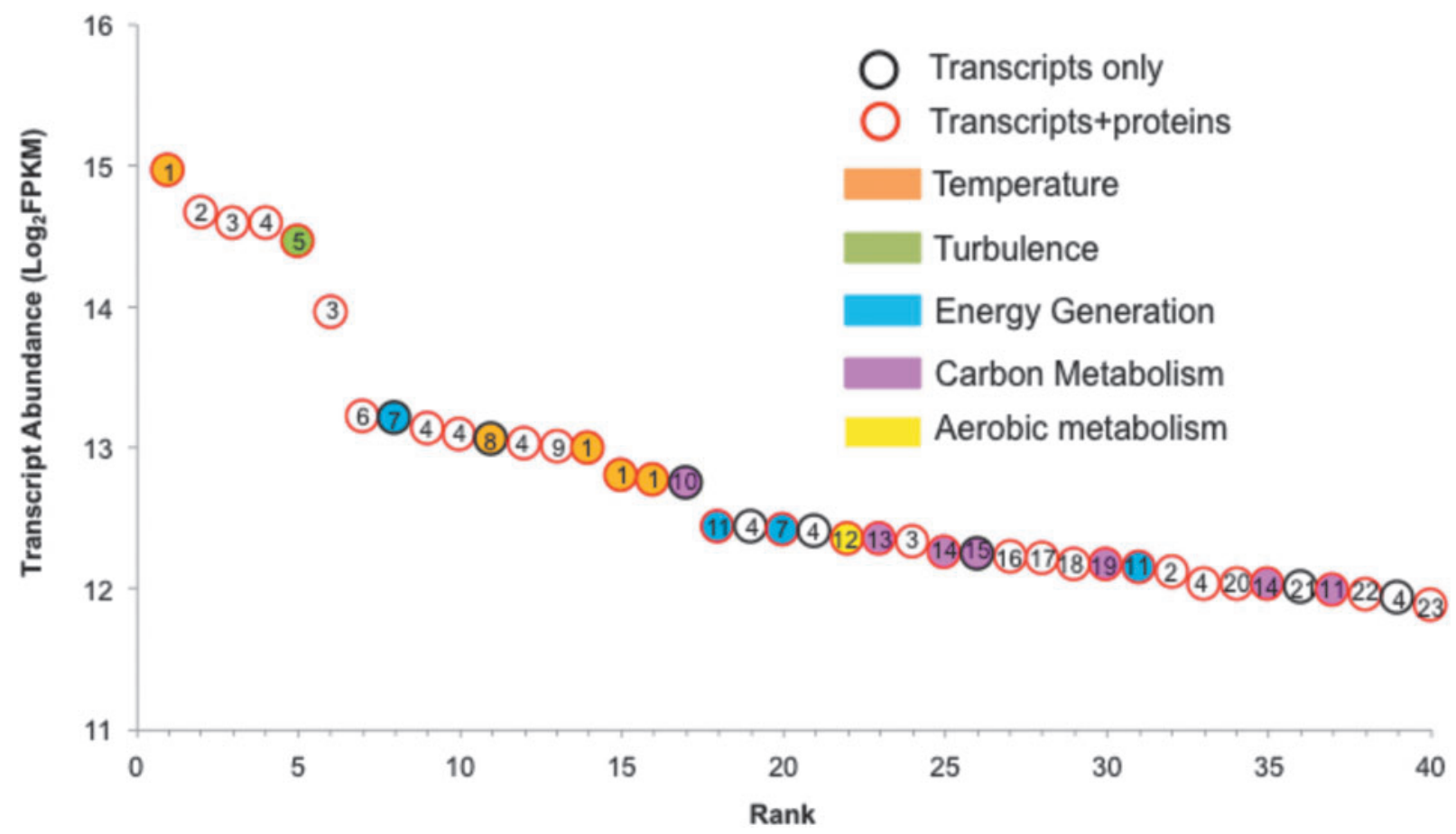

FIG. 8. The abundance of the top 40 expressed genes for the dominant Sulfurihydrogenibium spp. The transcript abundance was illustrated as the fragments per kilobase of transcript per million (FPKM) at logarithmic scale at the order of 2. The genes with both identified transcripts and cognate proteins were highlighted in red circles; the ones with only identified transcripts were shown in black circles. The circles were color coded if the genes were associated with response to temperature, turbulence, energy generation, or carbon metabolism. The numbers labeled inside the circles indicated the over-expressed genes: 1. chaperonin; 2 . GTPases; 3 . cytochrome c551/c552; 4. proteins of unknown function; 5. fimbrial protein; 6. NADH dehydrogenase; 7. rhodanese; 8. cold shock protein; 9. bacterial nucleoid DNA-binding protein; 10. isocitrate dehydrogenase; 11. polysulfide oxidoreductase; 12. truncated hemoglobins; 13. suncinyl-CoA synthetase; 14. succinate dehydrogenase; 15. desulfoferrodoxin; 16. ferredoxin; 17. cytochrome c; 18. F0F1-type ATP synthase; 19. pyruvate:ferredoxin oxidoreductase; 20. NADPH-dependent glutamate synthase; 21. acyl carrier protein; 22. translation initiation factor 1; 23. ABC-type phosphate transport system.

were collected in the present study. A conceptual model has been established that combines the geochemistry, hydrology, and multi-omics analyses of the Sulfurihydrogenibium-dominated filamentous microbial mats within the hot-spring drainage system (Fig. 9).

A suite of syntenous gene complexes (e.g., heterodisulfide reductases, and other Fe-S reductases, including $h d r$, sqr, rdh, sox, cox, psr/sre) has been identified in both Sulfurihydrogenibium genomes and filamentous microbial mat metagenomes (Reysenbach et al., 2009; Inskeep et al., 2010; Takacs-Vesbach et al., 2013). However, a pilot metatranscriptomic study showed expression of only one sulfide oxidation gene in the MHS streamer communities (Hamamura et al., 2013). Based on metagenomic and metatranscriptomic studies, Sulfurihydrogenibium spp. also contain and express genes for arsenic cycling, including the potential to oxidize arsenite or reduce arsenate via ArsC and extrude arsenite via an efflux pump (AsrB) transformation to methylate arsenite via methyl transferases (Inskeep et al., 2010; Hamamura et al., 2013; Takacs-Vesbach et al., 2013). The capacity to metabolize arsenic compounds has also been identified on $S$. azorense Az-Fu1 and S. subterraneum HGMK1 (Takai et al., 2003; Aguiar et al., 2004), which could use arsenite and arsenate as the electron donor and electron acceptor, respectively (Takai et al., 2003). In addition, detection of a series of cytochromes (e.g., cytochrome bd-I terminal oxidase, $\mathrm{cbb}_{3}$ heme $\mathrm{Cu}$ oxi- dase) implies that Sulfurihydrogenibium spp. likely respires oxygen as the terminal electron acceptor (Hamamura et al., 2013; Takacs-Vesbach et al., 2013). The MHS Sulfurihydrogenibium spp. streamers experience $\mathrm{As}^{3+}$ concentration of about $20 \mu \mathrm{M}$, which is in the same order of magnitude as the sulfide concentration $(100 \mu \mathrm{M})$ and implies that arsenite may be a significant energy source.

In addition, in order for the Sulfurihydrogenibiumdominated filamentous microbial community to survive the $70^{\circ} \mathrm{C}$ thermal stress, it must maintain cell integrity and enzymatic functions. Overexpressed transcripts and proteins associated with "helper" proteins and chaperonins would serve as adaptive physiological components that permit cell growth and replication (Figs. 7 and 8, Tables 1 and S11). Chaperonins facilitate appropriate folding of proteins at elevated temperature and prevent thermal denaturation by keeping them in a thermally stable configuration (Walter and Buchner, 2002).

\section{2. rTCA cycle}

Over-representation of the transcripts and the cognate proteins associated with the rTCA cycle support the interpretation of a chemoautotrophic lifestyle for the Sulfurihydrogenibium spp. in these $\mathrm{CO}_{2}$-enriched ACF-depositing environments (Figs. 7-9, Tables 1 and S7). Here, trace amounts of dissolved organic carbon $(\sim 40 \mu \mathrm{M})$ limit 


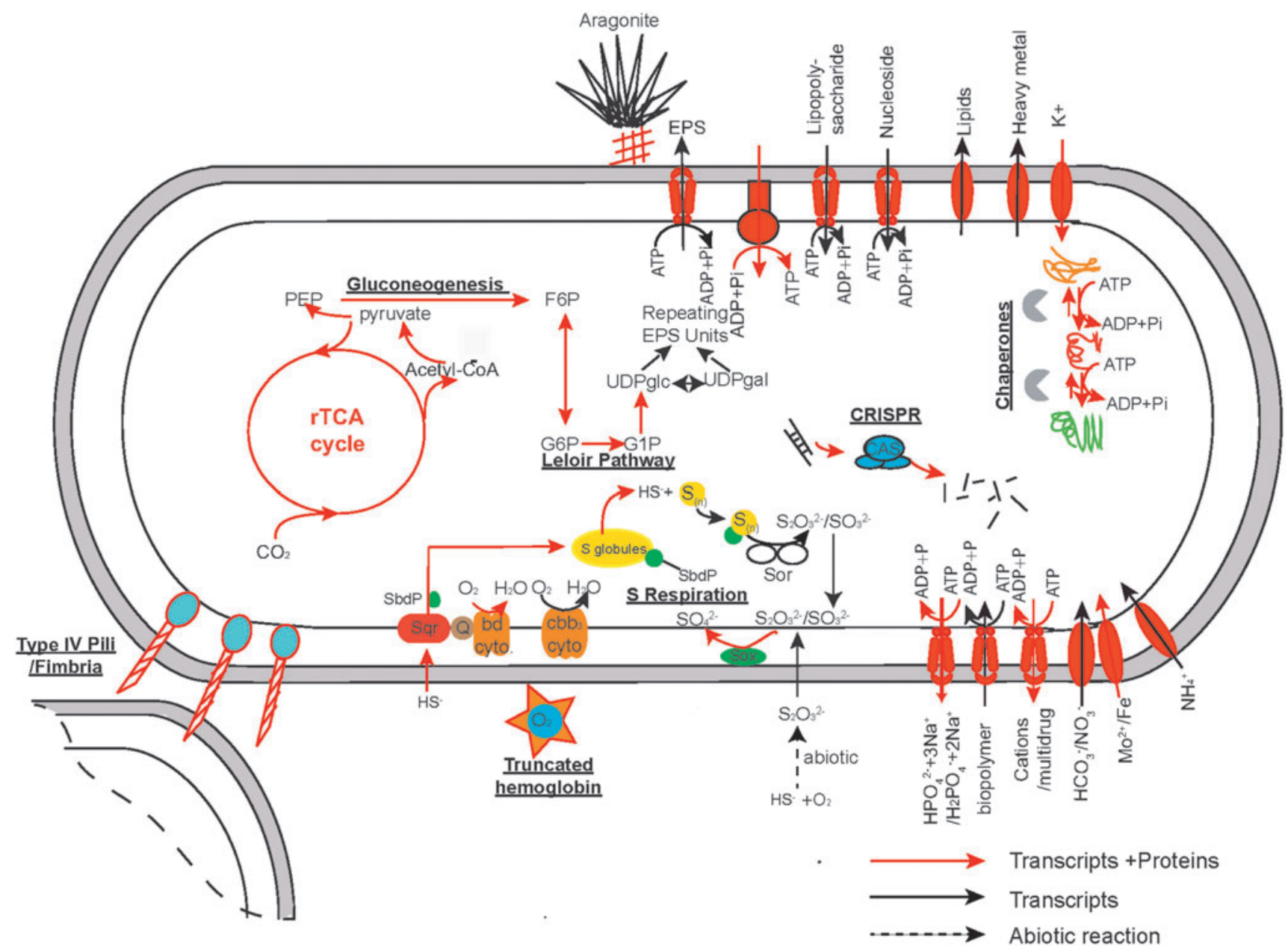

FIG. 9. Summary of reconstructed metabolic functions for the dominant Sulfurihydrogenibium spp. comprising the filamentous microbial mat community. Arrows connect successive steps of the metabolic pathways. Abbreviations: ATP: adenosine triphosphate; ADP: adenosine diphosphate; bd cyto: cytochrome bd-type quinol oxidase; CAS: CRISPRassociated genes; cbb3 cyto: cbb3-type cytochrome oxidase; F6P: fructose 6-phosphate; G6P: glucose 6-phosphate; G1P: glucose 1-phosphate; PEP: phosphoenolpyruvic acid; Q: quinone or ubiquinone; SbdP: sulfur-binding donating protein; $\mathrm{S}_{(\mathrm{n})}$ : zero valent sulfur; Sor: sulfur oxidation proteins; Sox: sulfite oxidase; Sqr: sulfide:quinone reductase; UDPglc: uridine diphosphate glucose; UDPgal: uridine diphosphate galactose.

heterotrophic metabolism. In addition, the temperature $\left(70-73^{\circ} \mathrm{C}\right)$ is close to the upper limit for phototrophic metabolism (Brock, 1998). The rTCA cycle is an ancient mechanism for carbon fixation and is found in all the Aquificales organisms (e.g., Sulfurihydrogenibium spp.; Hugler et al., 2007). This enables thermophilic microbes to take advantage of abundant products of dissolved $\mathrm{CO}_{2}$ and its dissociation products and act as the primary producers in many hot-spring ecosystems (Reysenbach et al., 2005; Inskeep et al., 2010, 2013; Fouke, 2011; Takacs-Vesbach et al., 2013). Presence of the rTCA cycle is further supported by the previous detection of phospholipid biomarkers and carbon isotopes in the same spring systems (Zhang et al., 2004). In general, Sulfurihydrogenibium species are strict chemoautotrophs (Takai et al., 2003; Aguiar et al., 2004; Nakagawa et al., 2005; Flores et al., 2008; O'Neill et al., 2008). Other examples include Sulfurihydrogenibiumdominated filamentous microbial communities from Coffee Pot Spring and the thermal vents in Yellowstone Lake that show biomarker genes affiliated with rTCA (e.g., aclA and $a c l \mathrm{~B})$. This suggests that the rTCA cycle is a conserved biosynthesis trait for this group of organisms (Hall et al., 2008; Yang et al., 2011). Compared to the ACF at MHS, Calcite Spring water in YNP has significantly higher dissolved organic carbon but lower concentrations of dissolved inorganic carbon. Here Sulfurihydrogenibium and Thermus spp. co-occur in the streamer microbial community (Inskeep et al., 2013; Takacs-Vesbach et al., 2013). In all of these locations, Sulfurihydrogenibium spp. does not dominate the filamentous microbial community.

\subsection{Sulfur cycle}

High concentrations of reduced sulfur compounds in ACF likely act as the primary energy source for the Sulfurihydrogenibium species (Figs. 7-9, Table S8). The functional genes, transcripts, and the cognate proteins associated with sulfide-quinone reductase (Sqr), sulfur oxidization proteins (SOX), and sulfide oxidase suggest Sulfurihydrogenibium spp. oxidizes a variety of reduced sulfur compounds 
(e.g., sulfide, $\mathrm{S}^{0}$, thiosulfate, and sulfide). These predicted ecophysiological features are consistent to the known Sulfurihydrogenibium isolates (Aguiar et al., 2004; Nakagawa et al., 2005; Flores et al., 2008; O’Neill et al., 2008). Some sulfur compounds $\left(e . g ., \mathrm{S}^{0}\right)$ are thermodynamically stable. These microorganisms transfer sulfur globules to the appropriate enzymes to generate more soluble forms of polysulfide, which in turn are transformed by rhodanese and polysulfide reductase (Aussignargues et al., 2012; Findlay, 2016) (Figs. 8 and 9; Table S8). Sulfurihydrogenibium-dominated filamentous mats found in hot springs around the world consistently contain reduced sulfur compounds (Reysenbach et al., 2009; Inskeep et al., 2010, 2013; Tamazawa et al., 2012; Hamamura et al., 2013; Takacs-Vesbach et al., 2013). The addition of $5 \mathrm{mM}$ thiosulfate to these mat communities enhances carbon fixation, and the oxidation of thiosulfate triggers energy production and biosynthesis (Yang et al., 2011). This may explain why hot springs with relatively low concentrations of reduced sulfur are not dominated by Sulfurihydrogenibium spp. even though other geochemical factors (e.g., $\mathrm{pH}$, temperature, and dissolved oxygen) are comparable (Yang et al., 2011; Hou et al., 2013).

\subsection{Aerobic respiration}

The expression of a variety of aerobic respiration-associated genes may be what enables Sulfurihydrogenibium spp. to adapt and thrive in the dysoxic spring water of the ACF. Aerobic respiration by Sulfurihydrogenibium spp. in the dysoxic waters of ACF deposition (Fig. 1; Table S1) may be facilitated by some functional enzymes such as truncated hemoglobin-like proteins and cytochrome bd-type quinol oxidase (Figs. 8 and 9; Table S8). Hemoglobin superfamilies are associated with a variety of respiratory reactions (e.g., NO dioxygenases or as $\mathrm{NO}$ detoxification components) under $\mathrm{O}_{2}$-limiting conditions (Frey and Kallio, 2003; Gardner, 2000). Over-expressed truncated hemoglobin-like proteins are found in Sulfurihydrogenibium spp. and also observed in filamentous Vitreoscilla under hypoxic conditions, which are consistent with the low levels of terminal cytochrome oxidases seen in E. coli (Hardison, 1996). In addition, the uptake of oxygen in dysoxic conditions by Sulfurihydrogenibium spp. may also be assisted by cytochromes (de Gier et al., 1996). These include cytochrome cbb3-type heme copper terminal oxidase and cytochrome bd-type quinol oxidase (Inskeep et al., 2010; TakacsVesbach et al., 2013). In addition, other alternative electron donating processes (e.g., hydrogen oxidation and arsenic oxidation) are also utilized by Sulfurihydrogenibium spp. (Spear et al., 2005; Hamamura et al., 2013). However, meta-omic evidence suggests that neither of these processes is critical for the Sulfurihydrogenibium populations in the ACF depositional environment (Supplementary Information and Table S8).

\subsection{Attachment of filamentous microbial mats}

The combined attachment effects of EPSs, type IV pili, and surface stabilization via aragonite crystallization permit Sulfurihydrogenibium spp. to successfully colonize and outcompete other microbial communities in these hot-spring drainage environments (Figs. 1, 7, and 8). Successful colonization of the hot, shallow, and turbulent outflow environments of ACF fettuccini travertine deposition requires that Sulfurihydrogenibium spp. attach to the bottom surface of the spring drainage channel to form the streaming filamentous cell aggregates (Figs. 1-3). This is consistent with microbial streamers observed in many other natural and engineered systems, which are described as having a characteristic "head" attachment and "tail" downflow undulating filaments (Hallberg et al., 2006; Niederberger et al., 2009; Vrouwenvelder et al., 2009; Ngene et al., 2010). This allows them to withstand the strong hydrodynamic shear forces that sweep other planktonic and/or weakly adhered microorganisms downstream. Combined field, microscopy, and multi-omics evidence collected in the present study suggests Sulfurihydrogenibium spp. has an integrated strategy for attachment and growth that utilizes EPS, type IV pili, and rapid aragonite crystal precipitation (Fig. 8 and Tables 1, S9, and S10). EPS traps cells, water, ions, and other organic compounds on surfaces (Flemming et al., 2000; Sutherland, 2001; Serra et al., 2013). EPS also mediates the transition from reversible to irreversible adhesion of single cells and thus facilitates further attachment of motile bacteria (Stoodley et al., 2002; Ducret et al., 2012). Overexpression of type IV pili-associated transcripts and proteins in MHS Sulfurihydrogenibium spp. (Tables 1 and S10) suggests that they utilize their pili to securely attach (Takai et al., 2003; Aguiar et al., 2004; Nakagawa et al., 2005; Flores et al., 2008; O'Neill et al., 2008). Unlike the swimming motility achieved by rotatory flagella, type IV pili facilitate colonization on hydrated organic or inorganic surfaces. Twitching motility is colonial in nature and usually involves cell-cell contact (Mattick, 2002).

Notably, flagella-associated transcripts are absent from the Sulfurihydrogenibium metatranscriptome at MHS but have been detected in filamentous microbial mats at Calcite Spring, YNP, and in the Azores (Hamamura et al., 2013). This may at least in part be due to environmental differences in hydrodynamics and crystallization rate between these three sites. With respect to flow, filamentous microbial mats in Calcite Spring and the Azores have significantly slower hot-spring water flow rates $\left(\sim 0.1 \mathrm{~m} \mathrm{~s}^{-1}\right.$ in Calcite Springs, $\sim 0.05 \mathrm{~m} \mathrm{~s}^{-1}$ in the Azores vs. $\sim 0.3 \mathrm{~m} \mathrm{~s}^{-1}$ in MHS [Reysenbach et al., 2005; Kandianis et al., 2008; TakacsVesbach et al., 2013]). Therefore, the flagella-associated genes in the lower-flow Calcite Springs and Azores systems may be expressed to allow organisms to be mobile and seek more optimal geochemical gradients. In contrast, the high flow rates in the ACF fettuccini streamer travertine depositing environments of MHS may prevent Sulfurihydrogenibium species from being equally motile (Hamamura et al., 2013). Our de novo assembly suggests that the Sulfurihydrogenibium phylotypes at MHS do contain genes for type IV pili, which may act as alternative motility appendages (Table S6). With respect to mineralization, Calcite Spring and those in the Azores have very low rates of pyrite and $S^{0}$ mineral precipitation (Hamamura et al., 2013), while travertine deposition at MHS is orders of magnitude higher at more than $5 \mathrm{~mm}$ per day (Fouke et al., 2000; Fouke, 2011; Inskeep et al., 2010, 2013; Takacs-Vesbach et al., 2013). This extremely rapid encrustation may therefore limit or even prevent motility of the Sulfurihydrogenibium-dominated filamentous mats.

\subsection{Fossilization of filamentous microbial mats}

Apron and Channel Facies fettuccini streamer travertine deposits are an unequivocal microbial biomarker that faithfully preserves the morphology of the Sulfurihydrogenibium- 
dominated microbial mats it entombs (Figs. 1-3). These deposits also create an environmentally sensitive and globally distributed fossil record of hot-spring water temperature, $\mathrm{pH}$, and flux (Veysey et al., 2008; Fouke, 2011; Okumura et al., 2012; Capezzuoli et al., 2014). Microbial metabolic processes that strongly influence ongoing travertine precipitation include the consumption and/or production of (1) $\mathrm{CO}_{2}$ during oxidation-reduction coupled metabolic reactions and photosynthesis; (2) organic and inorganic acids; and (3) membrane-bound biomolecules and enzymes on outer cell walls (Kandianis et al., 2008; Veysey et al., 2008). These factors combine to control $\mathrm{CaCO}_{3}$ precipitation rate, which in turn influences travertine mineralogy, chemistry, crystalline structure, porosity, and the preservation of other types of biomarkers such as biomolecules (i.e., proteins, lipids, metabolites) and catabolic waste products (i.e., isotopes, reduced electron acceptors).

Kandianis et al. (2008) demonstrated with controlled field experiments at MHS that the steady-state precipitation rate of ACF fettuccini streamer travertine was 2.5 times greater over a 3-day period at an aragonite saturation state $\left(\Omega_{\mathrm{a}}\right)$ of $3.63 \pm 0.09$ (which is near that of normal seawater) than when microbial biomass is removed from the growing surface. This is likely caused by cell membrane-bound biomolecules and EPS concentrations in the microbial mat biomass (Kandianis et al., 2008). This is consistent with previous studies that have shown proteins, polysaccharides, and lipids can alter $\mathrm{CaCO}_{3}$ nucleation rates by changing the activation energy required for precipitation (Kandianis et al., 2008; Jones and Peng, 2014; Cangemi et al., 2016). One mechanism for this may be the negatively charged functional groups (e.g., carboxyl, phosphate, and amine) on the microbial cell walls. These may either act as nucleation templates for adsorption of metal ions or create oversaturated crystal surface microenvironments for travertine precipitation (Warren et al., 2001; Fein, 2006).

Alternatively, the EPS synthesized and excreted by microorganisms may also enhance travertine precipitation. Genes for the biosynthesis of protein precursors for EPS are present in all the Sulfurihydrogenibium genomes, suggesting it is a universal physiological feature for this group (Fig. 4 and Table S5). The corresponding transcripts and cognate proteins in the present study are also consistent with EPS production (Fig. 2 and Table S9). Because acidic residues and sugars in EPS may trap divalent cations (e.g., $\mathrm{Ca}^{2+}$ and $\mathrm{Mg}^{2+}$ ), partial degradation of EPS could generate locally high concentrations of $\mathrm{Ca}^{2+}$ and thus favor carbonate precipitation (Dupraz et al., 2004). In addition, EPS can influence bacterial adhesion onto solid surfaces or improve the cohesion of sedimentary particles as during stromatolite (microbialite) formation (Tourney and Ngwenya, 2009, 2014). Modern travertine deposition in other hot springs has also observed that travertine preferentially nucleates on EPS, beginning with $5-80 \mathrm{~nm}$ diameter globules of amorphous calcium carbonates that coalesce and transform into well-developed acicular aragonite crystals (Greer et al., 2017).

The fettuccini streamers and ridged morphology of ACF travertine are a direct result of the entombment of Sulfurihydrogenibium-dominated microbial mats by aragonite (Figs. 1-3). Each original microbial filament, up to $2 \mathrm{~mm}$ in diameter and $10 \mathrm{~cm}$ in length, is composed of smaller intertwined micron-scale microbial filaments and coccoidal cells (Figs. 1-3). Thick sheets of EPSs are draped between the filaments and contain abundant elliptical holes that are created by gas bubble release, gravity stretching, and water turbulence (Figs. 1-3; Fouke, 2011). These microbial filaments and EPS sheets become rapidly encrusted by small $(<5 \mu \mathrm{m}$ long), densely packed aragonite needles. Significantly larger $(>>5 \mu \mathrm{m}$ long) aragonite needles grow in the EPS-rich interstitial void spaces (Fig. 3C). Larger acicular aragonite crystals eventually encrust each filament and the interstitial EPS (Fig. 3D, 3E).

Upstream-to-downstream distributions of microbial phospholipid fatty acids and glycolipid fatty acids (Zhang et al., 2004) parallel the travertine facies-specific microbial community partitioning indicated by $16 \mathrm{~S}$ rRNA gene sequence libraries (Fouke et al., 2003; Martin et al., 2010). These biomolecules are entombed and preserved within the solidphase streamer travertine, creating an invaluable additional biomarker to travertine morphology, crystalline fabric, and growth rate. Enrichment of fatty acid ${ }^{13} \mathrm{C}$ further supports the omics analyses in the present study, suggesting that these Sulfurihydrogenibium-dominated microbial communities are using the rTCA cycle (Zhang et al., 2004). Conversely, sulfur-isotope fractionation due to microbial processes is not readily preserved in the ACF fettuccini streamer travertine (Fouke et al., 2000). Microbial-driven sulfide oxidation in these environments is insufficient to overprint the large dissolved sulfur reservoir of the open spring system.

Field and microscope observations indicate that the Sulfurihydrogenibium-dominated microbial mats preferentially build up ridges of travertine on the bottom of the spring channels by combining the above-described suite of physiological and metabolic characteristics (Figs. 1-3). These run parallel to the downstream water flow direction, with the top of each ridge just millimeters below the flowing water surface. Clumps of living filaments are anchored solely on these ridges but not in the lows between ridges. Interpretations from the metagenomic, metatranscriptomic, and metaproteomic analyses suggest that these elevated travertine ridges maximize their access to miniscule amounts of dissolved oxygen, optimize their ability to attach and form large filaments that undulate in the down-current, and allow Sulfurihydrogenibium spp. to thrive in these hot-spring outflow channels at the virtual exclusion of other microorganisms.

\section{Conclusions}

Filamentous microbial mats that are $87-98 \%$ dominated by the bacterium Sulfurihydrogenibium spp. thrive in hightemperature fast-flowing turbulent water with steep redox gradients at MHS in YNP. Hot-spring travertine rapidly entombs these filamentous mats to form fettuccini-like travertine streamer microbial biomarkers that are important targets in the search for ancient fossilized microbial life on Earth and potentially other planets. Field observations integrated with geology, hydrology, microscopy, and multi-omic molecular biology analyses indicate that multiple Sulfurihydrogenibium spp. physiological and metabolic adaptations have allowed them to optimize their lifestyles in these hot-spring drainage environments to the virtual exclusion of other microorganisms. The formation of pili and EPS production allow for physical attachment and stability in these high-shear turbulent flow regimes. In addition, they combine the oxidation of reduced sulfur (e.g., sulfide, sulfur, or thiosulfate) with a simultaneous requirement for the uptake of 
extremely low concentrations of dissolved $\mathrm{O}_{2}$. This results in the deposition of centimeter-scale elevated travertine streamer ridges that allow Sulfurihydrogenibium spp. to access low levels of dissolved oxygen while optimizing their ability to anchor in turbulent outflow channels at the virtual exclusion of other microorganisms. These physiological and metabolic attributes of Sulfurihydrogenibium-dominated filamentous mat communities can be directly inferred and reconstructed from fossilized ridged travertine streamer microbial biomarker deposits.

\section{Acknowledgments}

This work was supported by the National Aeronautics and Space Administration (NASA) Astrobiology Institute (Cooperative Agreement No. NNA13AA91A) issued through the Science Mission Directorate. Research was completed under Yellowstone National Park (YNP) National Park Service (NPS) research permit number 3060R. Conclusions in this study are those of the authors and do not necessarily reflect those of the funding or permitting agencies. We gratefully acknowledge the many years of colleagueship and close working collaboration with NPS Rangers at YNP that made this work possible, including B. Fuhrmann, A. Rodman, C. Hendrix, H. Heasler, S. Sigler, and S. Haas.

\section{References}

Aguiar, P., Beveridge, T.J., and Reysenbach, A.L. (2004) Sulfurihydrogenibium azorense, sp. nov., a thermophilic hydrogen-oxidizing microaerophile from terrestrial hot springs in the Azores. Int J Syst Evol Microbiol 54:33-39.

Aussignargues, C., Giuliani, M.C., Infossi, P., Lojou, E., Guiral, M., Giudici-Orticoni, M.T., and Ilbert, M. (2012) Rhodanese functions as sulfur supplier for key enzymes in sulfur energy metabolism. J Biol Chem 287:19936-19948.

Blank, C.E., Cady, S.L., and Pace, N.R. (2002) Microbial composition of near-boiling silica-depositing thermal springs throughout Yellowstone National Park. Appl Environ Microbiol 68:5123-5135.

Brock, T.D. (1998) Early days in Yellowstone microbiology. ASM News 64:137-140.

Cangemi, M., Censi, P., Reimer, A., D’Alessandro, W., HauseReitner, D., Madonia, P., Oliveri, Y., Pecoraino, G., and Reitner, J. (2016) Carbonate precipitation in the alkaline lake Specchio di Venere (Pantelleria Island, Italy) and the possible role of microbial mats. Appl Geochem 67:168-176.

Capezzuoli, E., Gandin, A., and Pedley, M. (2014) Decoding tufa and travertine (fresh water carbonates) in the sedimentary record: the state of the art. Sedimentology 61:1-21.

de Gier, J.W., Schepper, M., Reijnders, W.N., van Dyck, S.J., Slotboom, D.J., Warne, A., Saraste, M., Krab, K., Finel, M., Stouthamer, A.H., van Spanning, R.J., and van der Oost, J. (1996) Structural and functional analysis of aa3-type and cbb3-type cytochrome c oxidases of Paracoccus denitrificans reveals significant differences in proton-pump design. Mol Microbiol 20:1247-1260.

Des Marais, D.J., Nuth, J.A., III, Allamandola, L.J., Boss, A.P., Farmer, J.D., Hoehler, T.M., Jakosky, B.M., Meadows, V.S., Pohorille, A., Runnegar, B., and Spormann, A.M. (2008) The NASA Astrobiology Roadmap. Astrobiology 8:715-730.

Dong, Y.R., Kumar, C.G., Chia, N., Kim, P.J., Miller, P.A., Price, N.D., Cann, I.K.O., Flynn, T.M., Sanford, R.A., Krapac, I.G., Locke, R.A., II, Hong, P.Y., Tamaki, H., Liu, W.T.,
Mackie, R.I., Hernandez, A.G., Wright, C.L., Mikel, M.A., Walker, J.L., Sivaguru, M., Fried, G., Yannarell, A.C., and Fouke, B.W. (2014) Halomonas sulfidaeris-dominated microbial community inhabits a $1.8 \mathrm{~km}$ deep subsurface Cambrian Sandstone reservoir. Environ Microbiol 16:1695-1708.

Ducret, A., Valignat, M.P., Mouhamar, F., Mignot, T., and Theodoly, O. (2012) Wet-surface-enhanced ellipsometric contrast microscopy identifies slime as a major adhesion factor during bacterial surface motility. Proc Natl Acad Sci USA 109:10036-10041.

Dupraz, C., Visscher, P.T., Baumgartner, L.K., and Reid, R.P. (2004) Microbe-mineral interactions: early carbonate precipitation in a hypersaline lake (Eleuthera Island, Bahamas). Sedimentology 51:745-765.

Fein, J.B. (2006) Thermodynamic modeling of metal adsorption onto bacterial cell walls: current challenges. Advances in Agronomy 90:179-202.

Ferrera, I., Longhorn, S., Banta, A.B., Liu, Y., Preston, D., and Reysenbach, A.L. (2007) Diversity of 16S rRNA gene, ITS region and aclB gene of the Aquificales. Extremophiles 11:57-64.

Findlay, A.J. (2016) Microbial impact on polysulfide dynamics in the environment. FEMS Microbiol Lett 363, doi:10.1093/ femsle/fnw 103.

Flemming, H.C., Wingender, J., Mayer, C., Korstgens, V., and Borchard, W. (2000) Cohesiveness in biofilm matrix polymers. In Community Structure and Cooperation in Biofilms: SGM Symposium Series 59, edited by D. Allison, P. Gilbert, H.M. Lappin-Scott, and M.K. Wilsons, Cambridge University Press, Cambridge, UK, pp 87-105.

Flores, G.E., Liu, Y., Ferrera, I., Beveridge, T.J., and Reysenbach, A.L. (2008) Sulfurihydrogenibium kristjanssonii sp nov., a hydrogen- and sulfur-oxidizing thermophile isolated from a terrestrial Icelandic hot spring. Int J Syst Evol Microbiol 58:1153-1158.

Fouke, B.W. (2001) Depositional facies and aqueous-solid geochemistry of travertine-depositing hot springs (Angel Terrace, Mammoth Hot Springs, Yellowstone National Park, USA) - Reply. J Sediment Res 71:497-500.

Fouke, B.W. (2011) Hot-spring systems geobiology: abiotic and biotic influences on travertine formation at Mammoth Hot Springs, Yellowstone National Park, USA. Sedimentology 58: 170-219.

Fouke, B.W. and Murphy, T. (2016) The Art of Yellowstone Science: Mammoth Hot Springs as a Window on the Universe. Crystal Creek Press, Livingston, MT.

Fouke, B.W., Farmer, J.D., Des Marais, D.J., Pratt, L., Sturchio, N.C., Burns, P.C., and Discipulo, M.K. (2000) Depositional facies and aqueous-solid geochemistry of travertine-depositing hot springs (Angel Terrace, Mammoth Hot Springs, Yellowstone National Park, USA). J Sediment Res 70:565-585.

Fouke, B.W., Bonheyo, G.T., Sanzenbacher, B., and FriasLopez, J. (2003) Partitioning of bacterial communities between travertine depositional facies at Mammoth Hot Springs, Yellowstone National Park, U.S.A. Can J Earth Sci 40:1531-1548.

Frey, A.D. and Kallio, P.T. (2003) Bacterial hemoglobins and flavohemoglobins: versatile proteins and their impact on microbiology and biotechnology. FEMS Microbiol Rev 27: 525-545.

Gardner, P.R., Gardner, A.M., Martin, L.A., Dou, Y., Li, T.S., Olson, J.S., Zhu, H., and Riggs, A.F. (2000) Nitric-oxide dioxygenase activity and function of flavohemoglobins Sensitivity to nitric oxide and carbon monoxide inhibition. J Biol Chem 275:31581-31587. 
Greer, H.F., Zhou, W.Z., and Guo, L. (2017) Reversed crystal growth of calcite in naturally occurring travertine crust. Crystals 7, doi:10.3390/cryst7020036.

Hall, J.R., Mitchell, K.R., Jackson-Weaver, O., Kooser, A.S., Cron, B.R., Crossey, L.J., and Takacs-Vesbach, C.D. (2008) Molecular characterization of the diversity and distribution of a thermal spring microbial community by using rRNA and metabolic genes. Appl Environ Microbiol 74:4910-4922.

Hallberg, K.B., Coupland, K., Kimura, S., and Johnson, D.B. (2006) Macroscopic streamer growths in acidic, metal-rich mine waters in north Wales consist of novel and remarkably simple bacterial communities. Appl Environ Microbiol 72:2022-2030.

Hamamura, N., Meneghin, J., and Reysenbach, A.L. (2013) Comparative community gene expression analysis of Aquificalesdominated geothermal springs. Environ Microbiol 15:12261237.

Hardison, R.C. (1996) A brief history of hemoglobins: plant, animal, protist, and bacteria. Proc Natl Acad Sci USA 93: $5675-5679$.

Hays, L., editor-in-chief. (2015) NASA Astrobiology Strategy 2015. Available online at http://astrobiology.nasa.gov/uploads/ filer_public/01/28/01283266-e401-4dcb-8e05-3918b21edb79/ nasa_astrobiology_strategy_2015_151008.pdf

Hou, W.G., Wang, S., Dong, H.L., Jiang, H.C., Briggs, B.R., Peacock, J.P., Huang, Q.Y., Huang, L.Q., Wu, G., Zhi, X.Y., Li, W., Dodsworth, J.A., Hedlund, B.P., Zhang, C., Hartnett, H.E., Dijkstra, P., and Hungate, B.A. (2013) A comprehensive census of microbial diversity in hot springs of Tengchong, Yunnan Province, China using 16S rRNA gene pyrosequencing. PLoS One 8, doi:10.1371/journal.pone.0053350.

Hugler, M., Huber, H., Molyneaux, S.J., Vetriani, C., and Sievert, S.M. (2007) Autotrophic $\mathrm{CO}_{2}$ fixation via the reductive tricarboxylic acid cycle in different lineages within the phylum Aquificae: evidence for two ways of citrate cleavage. Environ Microbiol 9:81-92.

Inskeep, W.P., Rusch, D.B., Jay, Z.J., Herrgard, M.J., Kozubal, M.A., Richardson, T.H., Macur, R.E., Hamamura, N., Jennings, R., Fouke, B.W., Reysenbach, A.L., Roberto, F., Young, M., Schwartz, A., Boyd, E.S., Badger, J.H., Mathur, E.J., Ortmann, A.C., Bateson, M., Geesey, G., and Frazier, M. (2010) Metagenomes from high-temperature chemotrophic systems reveal geochemical controls on microbial community structure and function. PLoS One 5, doi:10.1371/journal.pone.0009773.

Inskeep, W.P., Jay, Z.J., Herrgard, M.J., Kozubal, M.A., Rusch, D.B., Tringe, S.G., Macur, R.E., Jennings, R.D., Boyd, E.S., Spear, J.R., and Roberto, F.F. (2013) Phylogenetic and functional analysis of metagenome sequence from hightemperature archaeal habitats demonstrate linkages between metabolic potential and geochemistry. Front Microbiol 4, doi:10.3389/fmicb.2013.00095.

Jones, B. and Peng, X. (2014) Signatures of biologically influenced $\mathrm{CaCO}_{3}$ and $\mathrm{Mg}-\mathrm{Fe}$ silicate precipitation in hot springs: case study from the Ruidian geothermal area, western Yunnan Province, China. Sedimentology 61:56-89.

Kandianis, M.T., Fouke, B.W., Johnson, R.W., Veysey, J., and Inskeep, W.P. (2008) Microbial biomass: a catalyst for $\mathrm{CaCO}_{3}$ precipitation in advection-dominated transport regimes. Geol Soc Am Bull 120:442-450.

Markowitz, V.M., Chen, I.M., Palaniappan, K., Chu, K., Szeto, E., Grechkin, Y., Ratner, A., Jacob, B., Huang, J., Williams, P., Huntemann, M., Anderson, I., Mavromatis, K., Ivanova, N.N., and Kyrpides, N.C. (2012) IMG: the Integrated Microbial Genomes database and comparative analysis system. Nucleic Acids Res 40:D115-D122.
Martin, H.G., Veysey, J., Bonheyo, G.T., Goldenfeld, N., and Fouke, B.W. (2010) Statistical evaluation of bacterial 16S rRNA gene sequences in relation to travertine mineral precipitation and water chemistry at Mammoth Hot Springs, Yellowstone National Park, USA. In Geomicrobiology: Molecular and Environmental Perspective, edited by L.L. Barton, M. Mandi, and A. Loy, Springer, Dordrecht, the Netherlands, pp 239-249.

Mattick, J.S. (2002) Type IV pili and twitching motility. Аnnu Rev Microbiol 56:289-314.

Miller, C.S., Baker, B.J., Thomas, B.C., Singer, S.W., and Banfield, J.F. (2011) EMIRGE: reconstruction of full-length ribosomal genes from microbial community short read sequencing data. Genome Biol 12, doi:10.1186/gb-2011-12-5-r44.

Nakagawa, S., Shtaih, Z., Banta, A., Beveridge, T.J., Sako, Y., and Reysenbach, A.L. (2005) Sulfurihydrogenibium yellowstonense sp. nov., an extremely thermophilic, facultatively heterotrophic, sulfur-oxidizing bacterium from Yellowstone National Park, and emended descriptions of the genus Sulfurihydrogenibium, Sulfurihydrogenibium subterraneum and Sulfurihydrogenibium azorense. Int J Syst Evol Microbiol 55: 2263-2268.

Nakagawa, T. and Fukui, M. (2003) Molecular characterization of community structures and sulfur metabolism within microbial streamers in Japanese hot springs. Appl Environ Microbiol 69:7044-7057.

Ngene, I.S., Lammertink, R.G.H., Wessling, M., and Van der Meer, W.G.J. (2010) Particle deposition and biofilm formation on microstructured membranes. J Memb Sci 364:43-51.

Niederberger, T.D., Perreault, N.N., Lawrence, J.R., Nadeau, J.L., Mielke, R.E., Greer, C.W., Andersen, D.T., and Whyte, L.G. (2009) Novel sulfur-oxidizing streamers thriving in perennial cold saline springs of the Canadian High Arctic. Environ Microbiol 11:616-629.

Okumura, T., Takashima, C., Shiraishi, F., and Kano, A. (2012) Textural transition in an aragonite travertine formed under various flow conditions at Pancuran Pitu, Central Java, Indonesia. Sedimentary Geology 265-266:195-209.

O'Neill, A.H., Liu, Y., Ferrera, I., Beveridge, T.J., and Reysenbach, A.L. (2008) Sulfurihydrogenibium rodmanii sp. nov., a sulfur-oxidizing chemolithoautotroph from the Uzon Caldera, Kamchatka Peninsula, Russia, and emended description of the genus Sulfurihydrogenibium. Int J Syst Evol Microbiol 58:11471152.

Palmer, C.L., Thomer, A.K., Baker, K.S., Wickett, K.M., Hendrix, C.L., Rodman, A., Sigler, S., and Fouke, B.W. (2017) Site-based data curation based on hot spring geobiology. PloS ONE 12(3):e0172090.

Purcell, D., Sompong, U., Yim, L.C., Barraclough, T.G., Peerapornpisal, Y., and Pointing, S.B. (2007) The effects of temperature, $\mathrm{pH}$ and sulphide on the community structure of hyperthermophilic streamers in hot springs of northern Thailand. FEMS Microbiol Ecol 60:456-466.

Reysenbach, A.L., Banta, A., Civellow, S., Daly, J., Mitchel, K., Lalonde, S., Konhauser, K., Rodman, A., Rusterholtz, K., and Takacs-Vesbach, C. (2005) Aquificales in Yellowstone National Park. In Geothermal Biology and Geochemistry in Yellowstone National Park: Proceeding of the Thermal Biology Institute Workshop, edited by W.P. Inskeep, Montana State University Publications, Yellowstone National Park, WY, pp 130-142.

Reysenbach, A.L., Hamamura, N., Podar, M., Griffiths, E., Ferreira, S., Hochstein, R., Heidelberg, J., Johnson, J., Mead, D., Pohorille, A., Sarmiento, M., Schweighofer, K., Seshadri, R., 
and Voytek, M.A. (2009) Complete and draft genome sequences of six members of the Aquificales. J Bacteriol 191:1992-1993.

Rodriguez-Brito, B., Rohwer, F., and Edwards, R.A. (2006) An application of statistics to comparative metagenomics. BMC Bioinformatics 7:162.

Roling, W.F.M., Aerts, J.W., Patty, C.H.L., ten Kate, I.L., Ehrenfreund, P., and Direito, S.O.L. (2015) The significance of microbe-mineral-biomarker interactions in the detection of life on Mars and beyond. Astrobiology 15:492-507.

Serra, D.O., Richter, A.M., Klauck, G., Mika, F., and Hengge, R. (2013) Microanatomy at cellular resolution and spatial order of physiological differentiation in a bacterial biofilm. MBio 4, doi:10.1128/mBio.00103-13.

Spear, J.R., Walker, J.J., McCollom, T.M., and Pace, N.R. (2005) Hydrogen and bioenergetics in the Yellowstone geothermal ecosystem. Proc Natl Acad Sci USA 102:2555-2560.

Stoodley, P., Sauer, K., Davies, D.G., and Costerton, J.W. (2002) Biofilms as complex differentiated communities. Annu Rev Microbiol 56:187-209.

Sutherland, I.W. (2001) Biofilm exopolysaccharides: a strong and sticky framework. Microbiology 147:3-9.

Takacs-Vesbach, C., Inskeep, W.P., Jay, Z.J., Herrgard, M.J., Rusch, D.B., Tringe, S.G., Kozubal, M.A., Hamamura, N., Macur, R.E., Fouke, B.W., Reysenbach, A.L., McDermott, T.R., Jennings, R.D., Hengartner, N.W., and Xie, G. (2013) Metagenome sequence analysis of filamentous microbial communities obtained from geochemically distinct geothermal channels reveals specialization of three Aquificales lineages. Front Microbiol 4, doi:10.3389/fmicb.2013.00084

Takai, K., Kobayashi, H., Nealson, K.H., and Horikoshi, K. (2003) Sulfurihydrogenibium subterraneum gen. nov., sp nov., from a subsurface hot aquifer. Int J Syst Evol Microbiol 53:823-827.

Tamazawa, S., Takasaki, K., Tamaki, H., Kamagata, Y., and Hanada, S. (2012) Metagenomic and biochemical characterizations of sulfur oxidation metabolism in uncultured large sausage-shaped bacterium in hot spring microbial mats. PLoS One 7, doi:10.1371/journal.pone.0049793.

Tatusov, R.L., Galperin, M.Y., Natale, D.A., and Koonin, E.V. (2000) The COG database: a tool for genome-scale analysis of protein functions and evolution. Nucleic Acids Res 28: 33-36.

Thomer, A.K., Wickett, K.M., Baker, K.S., Fouke, B.W., and Palment, C.L. (2018) Documenting provenance in noncomputational workflows: Research process models based on geobiology fieldwork in Yellowstone National Park. J Assoc Inform Sci Technol 69:1234-1245.

Tourney, J. and Ngwenya, B.T. (2009) Bacterial extracellular polymeric substances (EPS) mediate $\mathrm{CaCO}_{3}$ morphology and polymorphism. Chem Geol 262:138-146.

Tourney, J. and Ngwenya, B.T. (2014) The role of bacterial extracellular polymeric substances in geomicrobiology. Chem Geol 386:115-132.

Veysey, J., Fouke, B.W., Kandianis, M.T., Schickel, T.J., Johnson, R.W., and Goldenfeld, N. (2008) Reconstruction of water temperature, $\mathrm{pH}$, and flux of ancient hot springs from travertine depositional facies. $J$ Sediment Res 78:69-76.

Vrouwenvelder, J.S., von der Schulenburg, D.A.G., Kruithof, J.C., Johns, M.L., and van Loosdrecht, M.C.M. (2009) Bio- fouling of spiral-wound nanofiltration and reverse osmosis membranes: a feed spacer problem. Water Res 43:583-594.

Walter, S. and Buchner, J. (2002) Molecular chaperonescellular machines for protein folding. Angewandte Chemie 41:1098-1113.

Wang, Y., Coleman-Derr, D., Chen, G., and Gu, Y.Q. (2015) OrthoVenn: a web server for genome wide comparison and annotation of orthologous clusters across multiple species. Nucleic Acids Res 1:W78-W84.

Warren, L.A., Maurice, P.A., Parmar, N., and Ferris, F.G. (2001) Microbially mediated calcium carbonate precipitation: implications for interpreting calcite precipitation and for solid-phase capture of inorganic contaminants. Geomicrobiol $J$ 18:93-115.

Yang, T.T., Lyons, S., Aguilar, C., Cuhel, R., and Teske, A. (2011) Microbial communities and chemosynthesis in Yellowstone Lake sublacustrine hydrothermal vent waters. Front Microbiol 2, doi:10.3389/fmicb.2011.00130.

Zhang, C.L., Fouke, B.W., Bonheyo, G.T., Peacock, A.D., White, D.C., Huang, Y.S., and Romanek, C.S. (2004) Lipid biomarkers and carbon-isotopes of modern travertine deposits (Yellowstone National Park, USA): implications for biogeochemical dynamics in hot-spring systems. Geochim Cosmochim Acta 68:3157-3169.

Zybailov, B., Mosley, A.L., Sardiu, M.E., Coleman, M.K., Florens, L., and Washburn, M.P. (2006) Statistical analysis of membrane proteome expression changes in Saccharomyces cerevisiae. J Proteome Res 5:2339-2347.

Address correspondence to: B.W. Fouke

Carl R. Woese Institute for Genomic Biology University of Illinois Urbana-Champaign 1206 W. Gregory Dr. Urbana, IL 61801

E-mail: fouke@illinois.edu

Submitted 1 October 2018 Accepted 14 March 2019

Supplementary Information may be found in the online version of this article at www.liebertonline.com/ast

\begin{aligned} \multicolumn{1}{c|}{ Abbreviations Used } \\ $\mathrm{ACF}=$ Apron and Channel Facies \\ $\mathrm{COGs}=$ clusters of orthologous groups of proteins \\ $\mathrm{EPSs}=$ extracellular polymeric substances \\ $\mathrm{MHS}=$ Mammoth Hot Springs \\ $\mathrm{ORFs}=$ open reading frames \\ rTCA cycle $=$ reversed tricarboxylic acid cycle \\ $\mathrm{SDS}=$ sodium dodecyl sulfate \\ $\mathrm{SOX}=$ sulfur oxidization proteins \\ $\mathrm{Sqr}=$ sulfide-quinone reductase \\ $\mathrm{SRA}=$ Short Reads Archive \\ $\mathrm{YNP}=$ Yellowstone National Park \end{aligned}

